\title{
Analyzing Design Heating Loads in Superinsulated Buildings
}

Lois Arena

Consortium for Advanced Residential Buildings 


\section{NOTICE}

This report was prepared as an account of work sponsored by an agency of the United States government. Neither the United States government nor any agency thereof, nor any of their employees, subcontractors, or affiliated partners makes any warranty, express or implied, or assumes any legal liability or responsibility for the accuracy, completeness, or usefulness of any information, apparatus, product, or process disclosed, or represents that its use would not infringe privately owned rights. Reference herein to any specific commercial product, process, or service by trade name, trademark, manufacturer, or otherwise does not necessarily constitute or imply its endorsement, recommendation, or favoring by the United States government or any agency thereof. The views and opinions of authors expressed herein do not necessarily state or reflect those of the United States government or any agency thereof.

Available electronically at http://www.osti.gov/bridge

Available for a processing fee to U.S. Department of Energy and its contractors, in paper, from:

U.S. Department of Energy

Office of Scientific and Technical Information

P.O. Box 62

Oak Ridge, TN 37831-0062

phone: 865.576.8401

fax: 865.576 .5728

email: mailto:reports@adonis.osti.gov

Available for sale to the public, in paper, from:

U.S. Department of Commerce

National Technical Information Service

5285 Port Royal Road

Springfield, VA 22161

phone: 800.553 .6847

fax: 703.605.6900

email: orders@ntis.fedworld.gov

online ordering: http://www.ntis.gov/ordering.htm 


\title{
Analyzing Design Heating Loads in Superinsulated Buildings
}

\author{
Prepared for: \\ The National Renewable Energy Laboratory \\ On behalf of the U.S. Department of Energy's Building America Program \\ Office of Energy Efficiency and Renewable Energy \\ 15013 Denver West Parkway \\ Golden, CO 80401 \\ NREL Contract No. DE-AC36-08GO28308 \\ Prepared by: \\ Lois Arena \\ Consortium for Advanced Residential Buildings \\ 61 Washington Street \\ Norwalk, CT 06854 \\ NREL Technical Monitor: Timothy Merrigan \\ Prepared under Subcontract No. KNDJ-0-40342-04
}

June 2015 
The work presented in this report does not represent performance of any product relative to regulated minimum efficiency requirements.

The laboratory and/or field sites used for this work are not certified rating test facilities. The conditions and methods under which products were characterized for this work differ from standard rating conditions, as described.

Because the methods and conditions differ, the reported results are not comparable to rated product performance and should only be used to estimate performance under the measured conditions. 


\section{Contents}

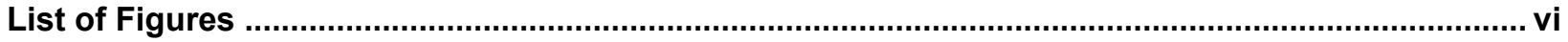

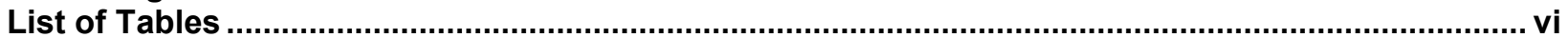

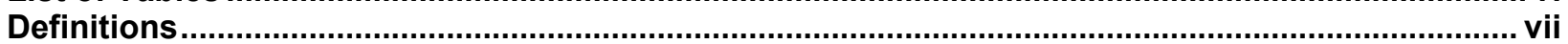

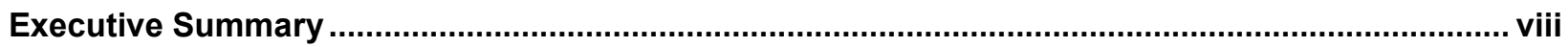

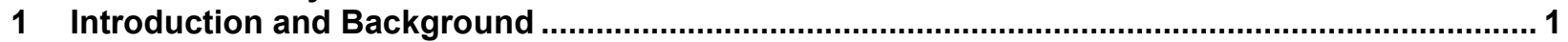

2 Research and Experimental Method

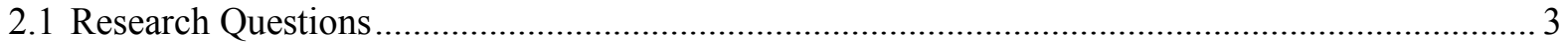

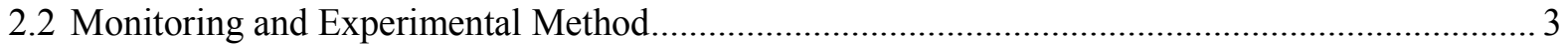

2.3 Comparing Manual J8 and Passive House Planning Package Predicted Design Loads ................ 4

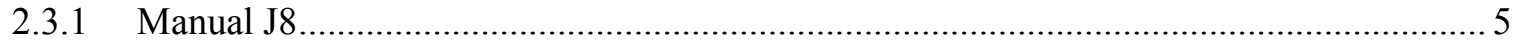

2.3.2 Passive House Planning Package ................................................................................ 5

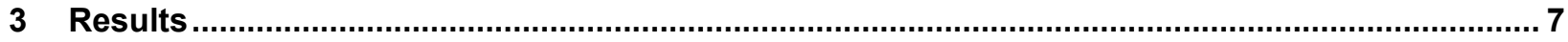

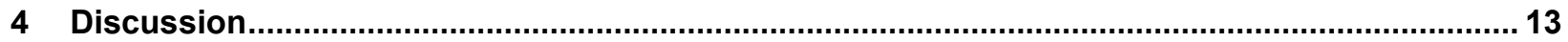

4.1 Recommendations for Sizing Heating Equipment for Superinsulated Buildings ........................ 15

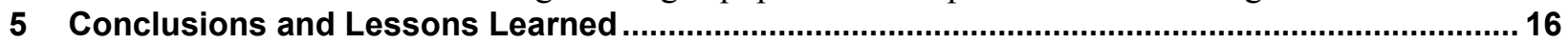

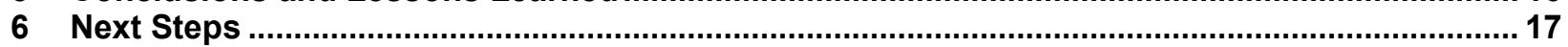

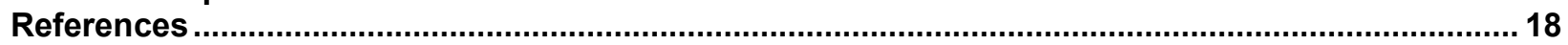

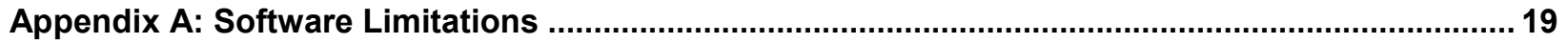

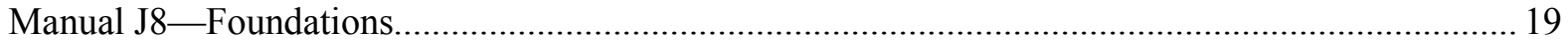

Manual J8 - Building Components ............................................................................................. 19

Appendix B: Using the Passive House Planning Package To Calculate Design Heating Loads ..... 22

Passive House Planning Package Inputs ...................................................................................... 23

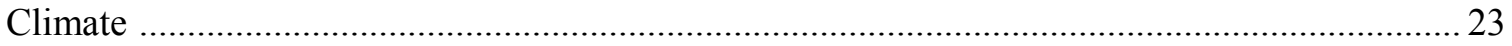

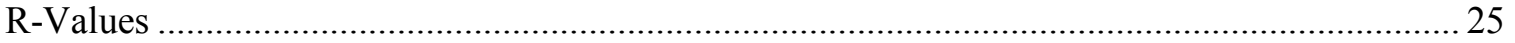

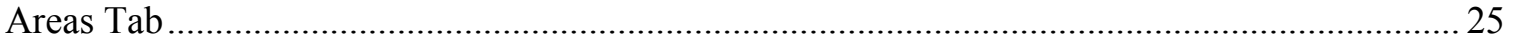

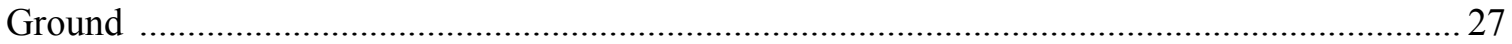

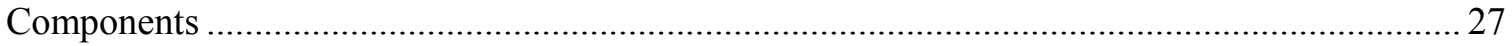

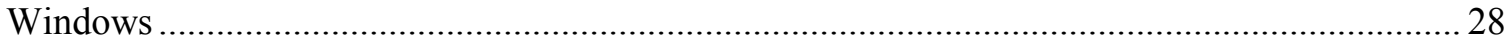

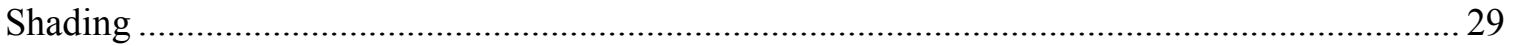

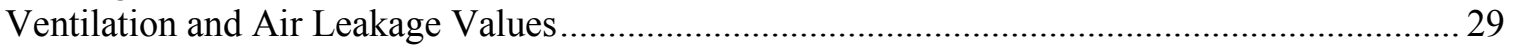

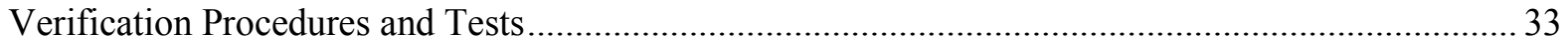

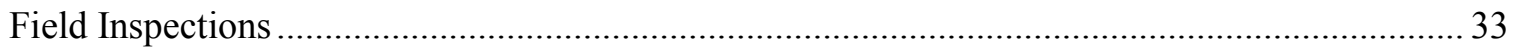

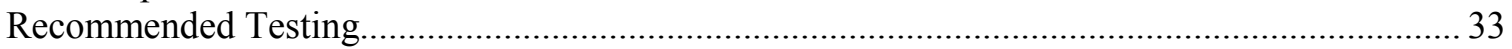




\section{List of Figures}

Figure 1. Finished homes in the Third Residential EcoVillage Experience development.................. 1

Figure 2. House 1: design heating loads compared to actual energy input at outdoor

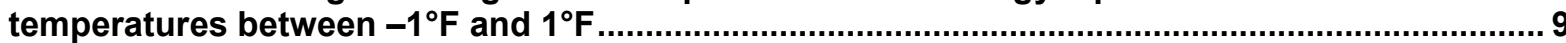

Figure 3. House 2: design heating loads compared to actual energy input at outdoor temperatures between $-1^{\circ} \mathrm{F}$ and $1^{\circ} \mathrm{F}$

Figure 4. House 1: design loads adjusted for actual interior temperatures, interior heat gains, and solar gains compared to measured input.......................................................................... 10

Figure 5. House 2: design loads adjusted for actual interior temperatures, interior heat gains, and solar gains compared to measured input.............................................................................. 11

Figure 6. Predicted design loads for House 1 compared to total input adjusted to reflect average DHW energy use from standby losses

igure 7. Predicted design loads for House 2 compared to total input adjusted to reflect average DHW energy use from standby losses

Figure 8. Design loads and measured input for House 1 compared to average indoor temperature

Figure 9. Design loads and measured input for House 2 compared to average indoor temperature

igure 10. Sketch of construction detail of slab-on-grade foundation

Figure 11. Screen shot of radio button input of the above-grade wall assembly with exterior rigid insulation in Wrightsoft software

Figure 12. Screen shot of radio button input of the above-grade wall assembly without exterior rigid insulation in Wrightsoft software.

Figure 13. Tabs in the PHPP that should be filled out for design heating load calculations............ 23

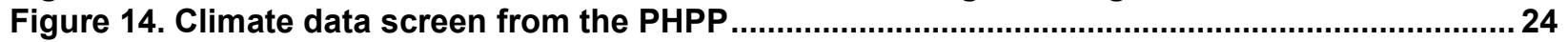

Figure 15. Screen shot showing the two different design conditions to be evaluated for this site. 24

Figure 16. Enter only the top line of each assembly section to save time. ......................................25

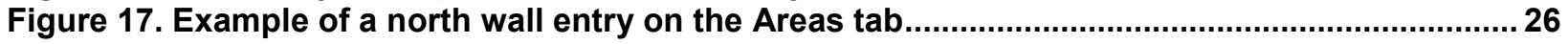

Figure 18. Example of a north wall orientation on the Areas tab...................................................... 26

Figure 19. Several ground sheet entries can be linked to the Areas and R-values tabs.................. 27

Figure 20. Drop-down boxes on the Windows tab allow the user to select the wall orientation

it is associated with from the Areas tab, the glazing type, and the frame type .......................... 28

Figure 21. The user must indicate whether the window abuts another window or a wall. .............. 29

Figure 22. The Ventilation tab also accounts for air leakage. ........................................................... 30

Figure 23. Ventilation rates can be adjusted to each particular project's needs............................ 31

Figure 24. Select the ERV/HRV from the drop-down box highlighted. If the unit being used is not in the list, enter the information on the Components tab.................................................... 32

Figure 25. Each building component should have a Btu/h value in the columns to the right.......... 33

Unless otherwise indicated, all figures were created by CARB.

\section{List of Tables}

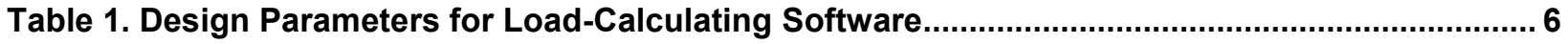

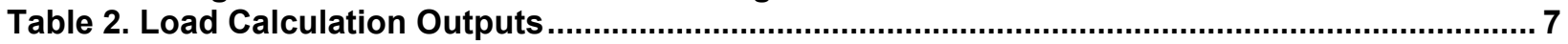

Table 3. Comparing Average Modeled Design Loads With Average Measured Input ..................... 12

Table 4. Percent Difference Compared to Total Input ..................................................................... 12

Unless otherwise indicated, all tables were created by CARB. 


\section{Definitions}

ACCA

$\mathrm{ACH}$

Building UA

CARB

DHW

ERV

HVAC

HRV

$\mathrm{PH}$

PHPP

SHGC
Air Conditioning Contractors of America

Air Changes per Hour

Characteristic whole-envelope heat transfer figure of merit. It represents a combined value for the entire envelope, including attic and roof, walls, windows, doors, and foundation.

Consortium for Advanced Residential Buildings

Domestic Hot Water

Energy Recovery Ventilator

Heating, Ventilating, and Air Conditioning

Heat Recovery Ventilator

Passive House

Passive House Planning Package

Solar Heat Gain Coefficient 


\section{Executive Summary}

The U.S. Department of Energy's Building America research team Consortium for Advanced Residential Buildings (CARB) worked with the EcoVillage cohousing community in Ithaca, New York, on the Third Residential EcoVillage Experience neighborhood. This communityscale project consists of 40 housing units - 15 apartments and 25 single-family residences. Units range in size from $450 \mathrm{ft}^{2}$ to $1,664 \mathrm{ft}^{2}$ and cost from $\$ 80,000$ for a studio apartment to $\$ 235,000$ for a three- or four-bedroom single-family home.

The community is pursuing certifications for the entire project for the following building standards: U.S. Department of Energy Zero Energy Ready Home, U.S. Green Building Council Leadership in Energy \& Environmental Design Gold, and ENERGY STAR ${ }^{\circledR}$. The four-story apartment building, the community center, and 7 of the 25 homes are being constructed to the Passive House (PH) design standard.

For the research component of this project, CARB analyzed current heating system sizing methods for superinsulated homes in cold climates to determine if changes in building load calculation methodology should be recommended. Actual heating energy use was monitored and compared to results from the Air Conditioning Contractors of America's Manual J8 (MJ8) and the Passive House Planning Package software. Results from that research indicate that MJ8 significantly oversizes heating systems for superinsulated homes and that thermal inertia and internal gains should be considered for more accurate load calculations.

For the two occupied homes, MJ8 calculations result in loads that are on average $56 \%$ higher than actual measured design loads; Passive House Planning Package calculations resulted in loads that were $34 \%$ higher on average. Based on these results, CARB recommends that designers use a method other than MJ8 for calculating design heating loads for superinsulated buildings and that thermal inertial and internal gains be included in sizing calculations. Doing so results in a closer approximation of the building's design load and still provides a slight buffer zone.

CARB anticipates that lessons learned and knowledge gained from this research will inform builders, designers, engineers, and consultants who are engaged in high-performance productionready residential projects. 


\section{Introduction and Background}

Many U.S. state codes and national efficiency programs require that the design heating load of residential buildings be calculated using the latest version (currently version 8 ) of the Air Conditioning Contractors of America's (ACCA) Manual J8 methodology (MJ8) or a similar calculation method. MJ8 is the primary residential design heating load calculation method used in the United States (ACCA 2009). However, for superinsulated homes adjustments to this standard or other methods for calculating loads may be warranted. Even when superinsulated homes aren't necessarily constructed with excessive mass in the form of concrete floors and walls, the amount of insulation and the increase in the thickness of the building envelope can have a mass effect, which means that the structure can store much more heat than a code-built home. This results in a very high thermal inertia, which makes the building much less sensitive to drastic temperature swings and decreases the peak heating load demand. Alternative methods that account for this inertia and solar and internal gains result in smaller and more appropriate design loads than those calculated using MJ8.

The U.S. Department of Energy's Building America research team Consortium for Advanced Residential Buildings (CARB) worked with the EcoVillage cohousing community in Ithaca, New York, on its third neighborhood - the Third Residential EcoVillage Experience. This community-scale project consists of 40 housing units - 15 apartments and 25 single-family residences-designed to accommodate different-size households. Units range in size from $450 \mathrm{ft}^{2}$ to $1,664 \mathrm{ft}^{2}$ and cost from $\$ 80,000$ for a studio apartment to $\$ 235,000$ for a three- or fourbedroom single-family home. A key precursor to developing highly efficient homes lies in the ability to optimize heating, ventilating, and air-conditioning (HVAC) equipment sizing and building component loss profiles that are based on accurate energy modeling results. In cooperation with several Ecovillage-Ithaca homeowners, CARB analyzed current mechanical system sizing methods for superinsulated homes in cold climates. Actual heating energy use was monitored and compared to results from MJ8 and the Passive House Planning Package (PHPP) software. This technical report details the findings of this research and provides guidance for modifying conventional sizing methods based on trends observed in this three-home analysis.

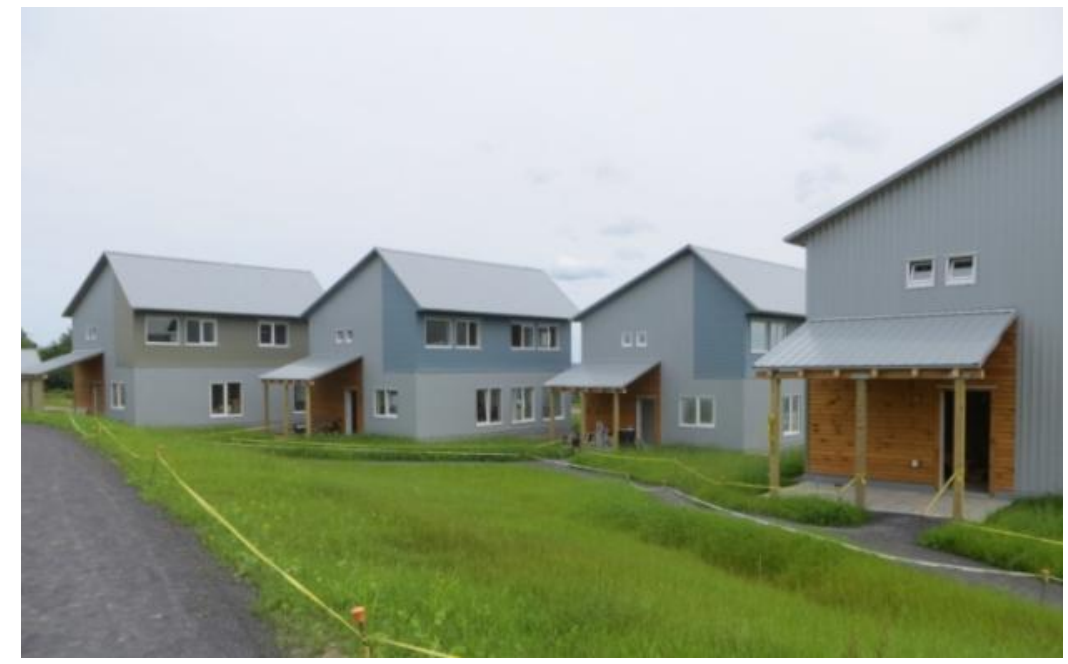

Figure 1. Finished homes in the Third Residential EcoVillage Experience development 
These recommendations are meant for use by experienced HVAC design professionals, energy consultants, and engineers for calculating design heat loads in superinsulated buildings for new and existing construction. If the system size is to be closely matched to the load, the project team must verify the performance. Third-party testing and inspections are necessary to ensure the home is constructed as designed. 


\section{Research and Experimental Method}

\subsection{Research Questions}

In this study, CARB sought to answer the following research questions:

- How do the design loads calculated using MJ8 and Passive House (PH) methods compare to the measured peak building loads?

- If the modeled loads are significantly different from the actual loads, can the differences be explained?

- What recommendations can be made about heating equipment sizing for superinsulated buildings?

\subsection{Monitoring and Experimental Method}

During the winter of 2013-2014, CARB monitored the energy use of three homes in climate zone 6 in an attempt to evaluate the accuracy of two different mechanical system sizing methods for low-load homes. The homes ranged from approximately $1,300 \mathrm{ft}^{2}$ to $1,650 \mathrm{ft}^{2}$. They are superinsulated structures with 12-in. thick walls at R-43 (or R-52 if PH), R-90 attics, R-35 under slab insulation, triple-pane windows with a solar heat gain coefficient (SHGC) of 0.52, and air leakage rates lower than 0.6 ACH@50 Pascals. Baseboard capacity was sized using MJ8 values (see Table 2 in Section 3). Loads were so small in these homes that they required only 9 linear $\mathrm{ft}$ of electric resistance baseboard.

Actual heating energy use was monitored and compared to predicted design heating loads from MJ8 and the PHPP, which are two very different sizing calculation methods.

The actual measured loads of the buildings were obtained from the input of the electric baseboard heaters. The following parameters were also measured:

- Inside temperature $\left({ }^{\circ} \mathrm{F}\right)$ in each room of the dwelling

- Outside temperature $\left({ }^{\circ} \mathrm{F}\right)$

- Energy consumption of electric resistance baseboard heaters (Btu)

- Building envelope areas $\left(\mathrm{ft}^{2}\right)$

- Appliance loads, including refrigerator, domestic hot water (DHW), energy recovery ventilator (ERV), and all plug loads (W).

Stove, dishwasher, and washing machine energy uses were also monitored separately, but these appliances were not used during the periods evaluated. Miscellaneous plug load energy use was calculated by subtracting the appliance and heating energy use from the total energy use recorded at the mains.

Powerhouse Dynamics' SiteSage Energy Monitor was used to collect long-term data. Current transformers were installed on the circuit breakers inside the electrical panel and connected to the SiteSage Energy Monitor base. This base communicates via wireless radio to the SiteSage Gateway, which in turn connects to the broadband service in the home. Data were stored on a cloud service from which they were accessed and downloaded as needed. 
Actual peak heating loads were calculated using temperature data collected onsite and the overall building UA values for each home. Only hourly blocks of data that met the following conditions were used in the analysis:

- Outdoor temperatures fell between $-1^{\circ} \mathrm{F}$ and $1^{\circ} \mathrm{F}\left(0^{\circ} \mathrm{F}\right.$ was the outdoor design temperature used in MJ8).

- Hours fell between 12 a.m. and 6 a.m. to eliminate any effects of solar heat gains.

When these conditions were met, the following hourly values were calculated:

- Total electricity use

- Heating energy use

- Appliance energy use

- Miscellaneous plug loads.

Actual loads were calculated by multiplying the design UA values from MJ8 and PH by the measured temperature difference. Interior temperatures used in the calculations were the average of all room sensor readings. Building UA values were calculated by dividing the design heating loads by the design temperature differences as shown in Equation 1:

$$
U A=\frac{Q_{\text {design }}}{\Delta T_{\text {design }}}
$$

where,

$$
\begin{array}{ll}
\mathrm{UA}= & \text { overall heat loss coefficient }\left(\mathrm{Btu} / \mathrm{h} /{ }^{\circ} \mathrm{F}\right) \\
Q_{\text {design }}= & \text { design load }(\mathrm{Btu} / \mathrm{h}) \\
\Delta T_{\text {design }}= & \text { design temperature difference }\left({ }^{\circ} \mathrm{F}\right)
\end{array}
$$

Actual load, $Q_{a c t}$, for each design load calculation method was calculated per Equation 2:

$$
Q_{a c t}=U A \times \Delta T_{\text {meas }}
$$

where,

$$
\begin{array}{ll}
Q_{a c t}= & \text { actual load }(\mathrm{Btu} / \mathrm{h}) \\
\Delta T_{\text {meas }}= & \text { measured temperature difference }\left({ }^{\circ} \mathrm{F}\right)
\end{array}
$$

Internal gains from appliances and people and the overall heat transfer coefficient of the building envelope assembly were calculated and/or measured when possible and verified against predicted values.

\subsection{Comparing Manual J8 and Passive House Planning Package Predicted Design Loads}

CARB researchers used both sizing software packages to calculate design loads. Because the homes were identical and adjacent to each other (same orientation), the design loads apply to all the test homes. The following sections discuss significant differences in modeling methods and 
describe the key inputs that drive the model's calculations. Additional limitations of the software are outlined in Appendix A.

\subsubsection{Manual J8}

MJ8 is the primary standard used in the United States to calculate residential design heating and cooling loads (ACCA 2009). However, MJ8 states in Section 2 that this method should not be used for "solar homes that have passive features." Although the term passive features is vague, many homes built to the PH standard incorporate sun tempering by increasing south-facing glazing and its corresponding SHGC to provide solar heating during the winter months. These homes aren't typically built with excessive mass in the form of concrete floors and walls; however, the amount of insulation in the structure can have a mass effect and store much more heat than a code-built home. Therefore, the question is whether MJ8 is appropriate for superinsulated buildings with sun-tempering strategies.

MJ8 envelope loads include those for foundation, walls, ceiling/roof, and fenestration heat loss. HVAC equipment loads include duct losses and ventilation loads. Following recommended sizing protocols, the $1 \%$ winter design temperature $\left(0^{\circ} \mathrm{F}\right.$ in Ithaca, New York $)$ was selected along with an indoor temperature of $70^{\circ} \mathrm{F}$. For this project, Wrightsoft's Right-Suite Universal 2015 Version 12.0 was used to implement the MJ8 calculations. Design loads were calculated for each room and the electric baseboards were sized accordingly.

\subsubsection{Passive House Planning Package}

Load calculations for sizing heating equipment using the PHPP software were performed in a similar fashion with a few key exceptions.

Table 1 compares the design parameters from MJ8 and the PHPP. PHPP climate files are based on data from the World Meteorological Organization, which uses a period of 30 years for climate norms. These files are used to analyze climatic trends. Detailed hourly values are used for the dynamic building simulations performed when determining the two different outdoor design temperatures that are used in design heating load calculations in the PHPP. Those 2 days represent:

- A cold but sunny winter day with a cloudless sky (high pressure weather situation): weather condition 1 or

- A moderately cold but overcast day with minimal solar radiation: weather condition 2 (Feist 2007).

These temperatures are daily averages and represent the maximum heating load days.

Heating loads are calculated for both conditions and the larger of the two is used to size the equipment. The resulting outdoor design temperatures for Ithaca, New York, in the PHPP were $14.6^{\circ} \mathrm{F}$ and $15.2^{\circ} \mathrm{F}$, respectively.

The PHPP also uses different interior design parameters. The interior design temperature used is $68^{\circ} \mathrm{F}$ for PHPP as opposed to $70^{\circ} \mathrm{F}$ for MJ8. This difference resulted in temperature differences between the interior and exterior of $53^{\circ} \mathrm{F}$ for PHPP load calculations as opposed to $70^{\circ} \mathrm{F}$ using MJ8. 
Table 1. Design Parameters for Load-Calculating Software

\begin{tabular}{|c|c|c|c|}
\hline \multirow{2}{*}{ Parameters } & \multirow{2}{*}{ Manual J8 } & \multicolumn{2}{|c|}{ PHPP } \\
\hline & & Weather Condition 1 & Weather Condition 2 \\
\hline Outside Design Temperature & $0^{\circ} \mathrm{F}$ & $14.6^{\circ} \mathrm{F}$ & $15.2^{\circ} \mathrm{F}$ \\
\hline Indoor Design Temperature & $70^{\circ} \mathrm{F}$ & $68^{\circ} \mathrm{F}$ & $68^{\circ} \mathrm{F}$ \\
\hline Interior Relative Humidity & $40 \%$ & $55 \%$ & $55 \%$ \\
\hline Mean Earth Temperature & $50^{\circ} \mathrm{F}$ & $42^{\circ} \mathrm{F}$ & $42^{\circ} \mathrm{F}$ \\
\hline Conditioned Area $\left(\mathrm{ft}^{2}\right)$ & 1,664 & 1,267 & 1,267 \\
\hline Conditioned Volume $\left(\mathrm{ft}^{3}\right)$ & 13,312 & 10,389 & 10,389 \\
\hline
\end{tabular}

Another difference is in the calculation of the exterior surface areas. For the PH, the wall height is measured from the top of the roof insulation at the wall's edge to the bottom of the slab foundation. This measurement results in a higher wall area than would be calculated in MJ8. Thermal bridge calculations are then performed for the wall/roof and wall/foundation intersections and are added or subtracted as applicable.

The calculation of the conditioned volume is also significantly different in the PHPP. Conventional practice in the United States is to use the outside dimensions of the building envelope to calculate the conditioned square footage and then multiply that area by the ceiling height to find the volume. For PHPP inputs, only the interior floor area is used and any interior walls are eliminated.

Finally, internal and solar gains are deducted from the total design load in the PHPP, whereas MJ8 ignores both for design heating load calculations. 


\section{Results}

Table 2 shows that these two methods of calculating heating load resulted in a $42 \%$ difference in the total predicted design loads: 9,059 Btu/h for MJ8 and 5,352 Btu/h for PHPP (higher of the two loads is used). For a more precise comparison, the calculations were rerun in MJ8 using the PHPP interior and exterior design temperatures and volume. The resulting heating load of 6,674 $\mathrm{Btu} / \mathrm{h}$ is very close to the PHPP heating load of $6,861 \mathrm{Btu} / \mathrm{h}$ before subtracting solar and internal gains. The biggest differences between the two appear to be related to the predicted losses associated with the walls and slab floors. Because the wall areas used in PHPP are almost 50\% higher than that in MJ8, the differences in those component loads are understandable.

Table 2. Load Calculation Outputs

\begin{tabular}{c|c|c|c|c}
\hline \multirow{2}{*}{$\begin{array}{c}\text { Building } \\
\text { Heating Loads }\end{array}$} & \multirow{4}{|c}{ Heating Load Values (Btu/h) } \\
\cline { 4 - 5 } & $\mathbf{4 J 8}$ & MJ8 With PH & \multicolumn{2}{|c}{ PH } \\
\cline { 4 - 5 } & & Parameters & Weather Condition & Weather Condition \\
\hline Walls & 2,196 & 1,663 & $\mathbf{1}$ & $\mathbf{2}$ \\
\hline Glazing & 2,750 & 2,082 & 2,122 & 2,100 \\
\hline Doors & 412 & 312 & 299 & 296 \\
\hline Floors & 1,259 & 953 & 723 & 723 \\
\hline Ceiling & 641 & 485 & 474 & 469 \\
\hline Infiltration & 1,641 & 991 & 977 & 181 \\
\hline Ventilation & 188 & 188 & 183 & $\mathbf{6 , 8 6 1}$ \\
\hline Subtotal & $\mathbf{9 , 0 5 9}$ & $\mathbf{6 , 6 7 4}$ & $\mathbf{6 , 9 1 7}$ & -867 \\
\hline Solar Heat Gain & 0 & 0 & $-1,627$ & -643 \\
\hline Internal Gain & 0 & 0 & -643 & $\mathbf{5 , 3 5 2}$ \\
\hline Total & $\mathbf{9 , 0 5 9}$ & $\mathbf{6 , 6 7 4}$ & $\mathbf{4 , 6 4 7}$ & \\
\hline
\end{tabular}

The PHPP predicted load for the slab is $723 \mathrm{Btu} / \mathrm{h}$ and is $24 \%$ less than that predicted by MJ8$953 \mathrm{Btu} / \mathrm{h}$. The fundamental difference between the method by which the two tools calculate the losses through the floor is that MJ8 multiplies a thermal resistance factor- F-value - by the perimeter of the slab as follows in Equation 3:

where,

$$
Q_{\text {slab }}=F P \Delta T
$$

$\begin{array}{lll}\mathrm{F} & = & \mathrm{F}-\mathrm{value}, \text { Slab edge conductance }\left(\mathrm{Btu} / \mathrm{h}-{ }^{\circ} \mathrm{F}-\mathrm{ft}\right) \\ \mathrm{P} & = & \text { Perimeter of slab-on-grade foundation }(\mathrm{ft}) \\ \Delta \mathrm{T} & = & \begin{array}{l}\text { Difference between outdoor design temperature and indoor design } \\ \text { temperature }\left({ }^{\circ} \mathrm{F}\right)\end{array}\end{array}$

F-values are taken from Table 4A in the MJ8 standard and are provided for insulation levels up to R-15. If different slab insulation levels are present compared to Table 4A, the user must calculate a custom F-value for the slab as outlined on page 518 of the standard (see Appendix A for additional information). The F-value calculated for the Third Residential EcoVillage 
Experience was $0.155 \mathrm{Btu} / \mathrm{ft} \cdot{ }^{\circ} \mathrm{F} \cdot \mathrm{h}$. Similar soil conductivities were used in both sizing calculations.

Slab losses in the PHPP are calculated by multiplying the U-value through the body of the slab (as opposed to the perimeter) by the surface area of the slab as shown in Equation 4:

$$
Q_{\text {slab }}=U A \Delta T
$$

where,

$\mathrm{U}=$ Overall heat transfer coefficient of slab-on-grade foundation $\left(\mathrm{Btu} / \mathrm{h}-{ }^{\circ} \mathrm{F}-\mathrm{ft}^{2}\right)$

A $=$ Footprint area of slab-on-grade foundation $\left(\mathrm{ft}^{2}\right)$

$\Delta \mathrm{T}=$ Difference between ground design temperature and indoor design temperature $\left({ }^{\circ} \mathrm{F}\right)$

The perimeter losses are accounted for by calculating the thermal bridge (Psi value) between the slab and wall at the slab edge and multiplying that value by the perimeter length of the slab edge. This value is then added to the heat loss calculated through the floor of the slab.

Figure 2 and Figure 3 display the results of the monitoring compared to the predicted design values from MJ8 and the PHPP. The heating input energy never exceeds the PHPP design load predictions; total input energy exceeds the PHPP design loads in only 6 of the 54 sample sets. Because all end uses measured during these periods were electric, CARB assumed that all energy use resulted in heat input into the space; therefore, total input energy is being evaluated as the amount of mechanical heat provided - not just that from the baseboard heaters.

To determine the influence of actual interior temperatures on the design loads, MJ8 loads were recalculated using measured interior temperatures and displayed in the graph. Even though the difference between the adjusted loads and the design load was almost 1,500 Btu/h at times, the adjusted MJ8 loads were still significantly higher than the total input into the spaces. 


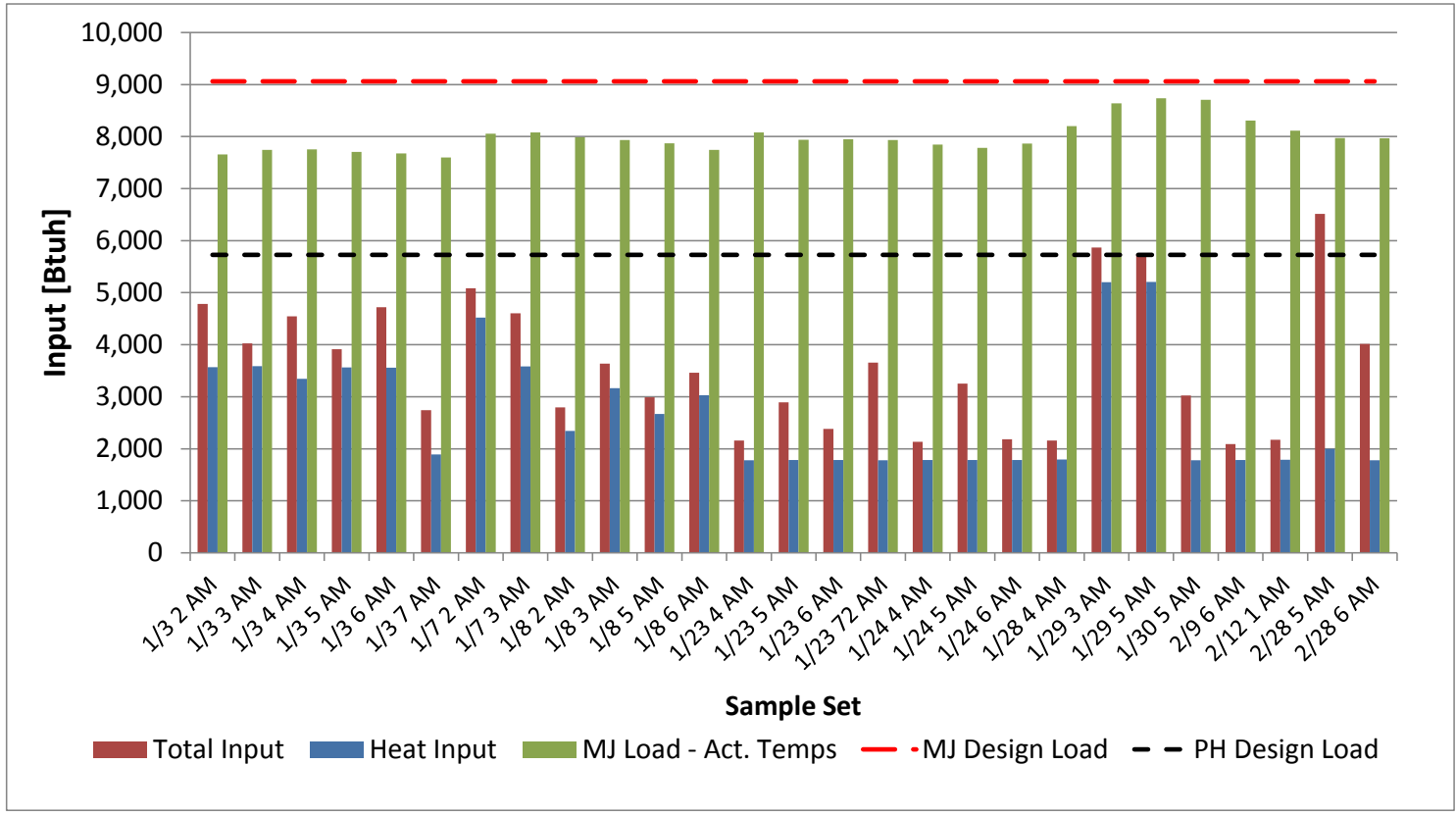

Figure 2. House 1: design heating loads compared to actual energy input at outdoor temperatures between $-1^{\circ} \mathrm{F}$ and $1^{\circ} \mathrm{F}$

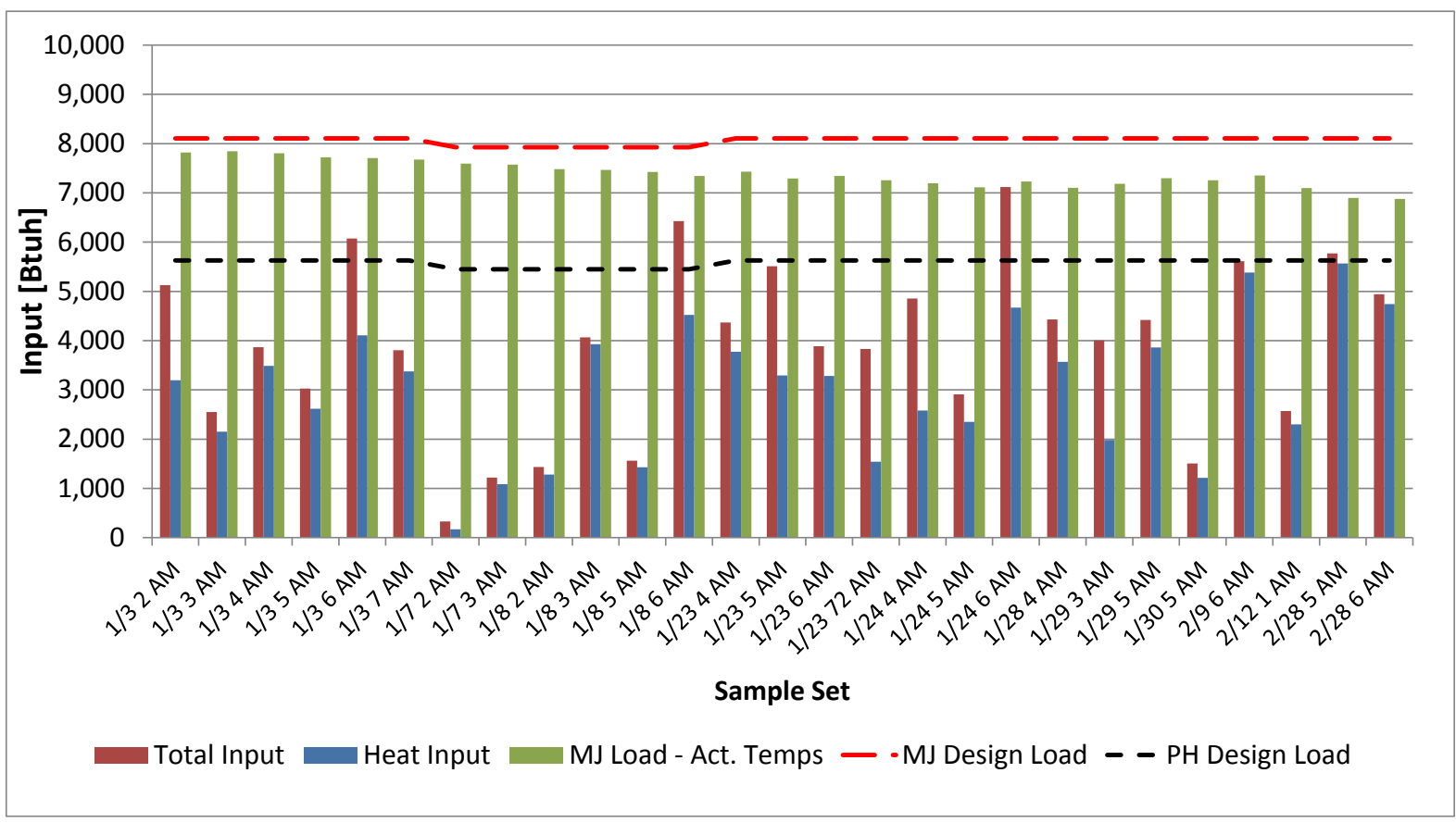

Figure 3. House 2: design heating loads compared to actual energy input at outdoor temperatures between $-1^{\circ} \mathrm{F}$ and $1^{\circ} \mathrm{F}^{1}$

\footnotetext{
${ }^{1}$ The ERV in House 2 was inoperable for periods 7 through 11; therefore, the design loads were adjusted appropriately for both MJ8 and the PHPP.
} 
As stated earlier, the PHPP design loads include internal heat gains and solar gains. Figure 4 and Figure 5 display the MJ8 predicted loads that were adjusted for these gains and the PHPP loads that were adjusted for actual indoor temperatures. With these adjustments, both load calculations now include internal and solar gains and have been adjusted for the actual interior temperatures to provide a side-by-side comparison of each calculation method.

Wintertime internal heat gains are calculated in the PHPP by multiplying a standard value of $0.507 \mathrm{Btu} / \mathrm{h} \cdot \mathrm{ft}^{2}$, which results in $643 \mathrm{Btu} / \mathrm{h}$ for each home. Predicted solar gains are calculated by evaluating solar radiation available on a sunny cold day and that on a cloudy warmer day. The available Btu/h$\cdot \mathrm{ft}^{2}$ from the sun for each orientation is then multiplied by the window area, the center-of-glass solar factor, and the shading factor. The resulting gains were $867 \mathrm{Btu} / \mathrm{h}$ and 816 $\mathrm{Btu} / \mathrm{h}$ for Homes 1 and 2, respectively. The solar gains from the PHPP were also added to the total input for each home to evaluate the validity of those assumptions.

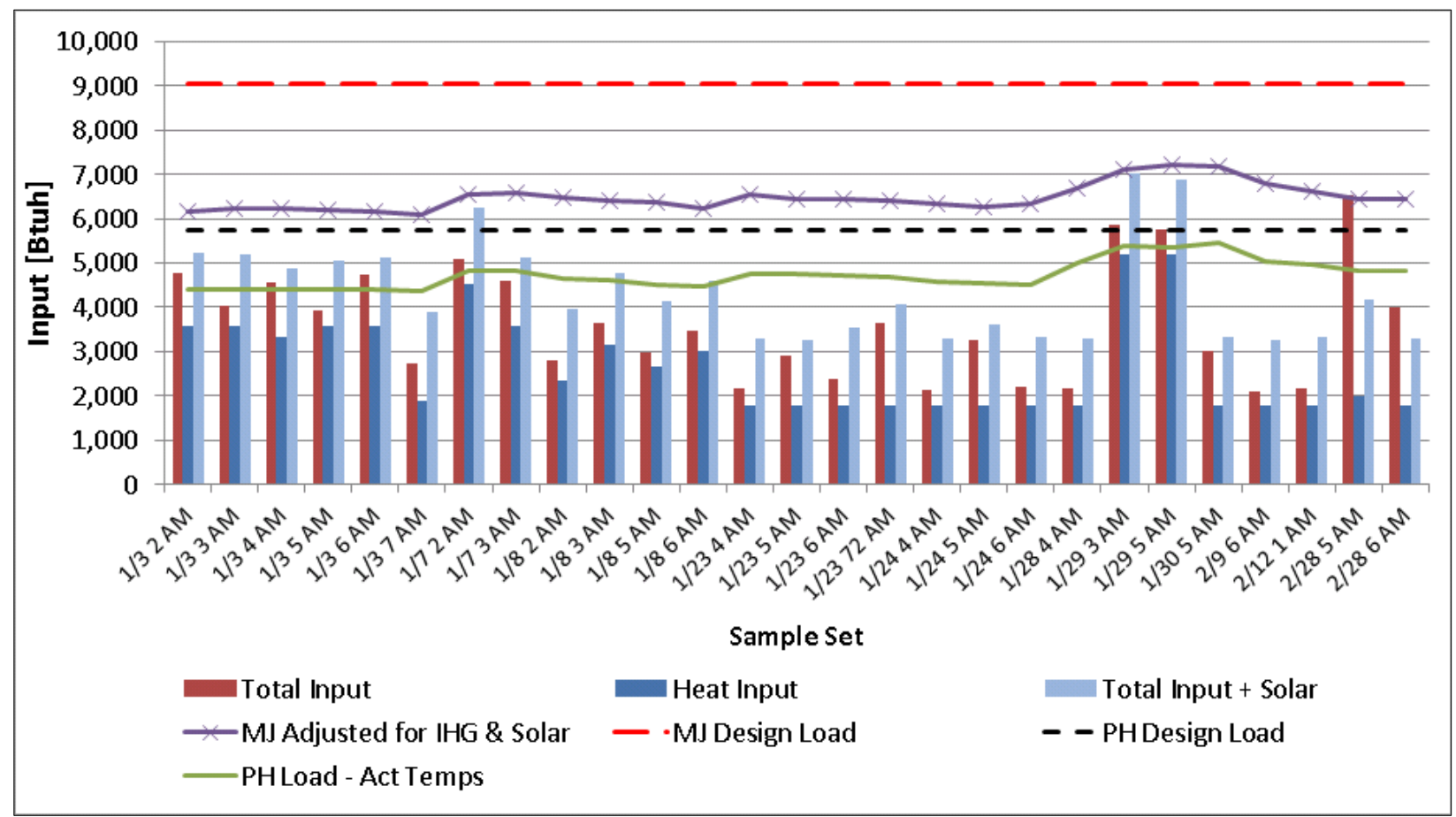

Figure 4. House 1: design loads adjusted for actual interior temperatures, interior heat gains, and solar gains compared to measured input 


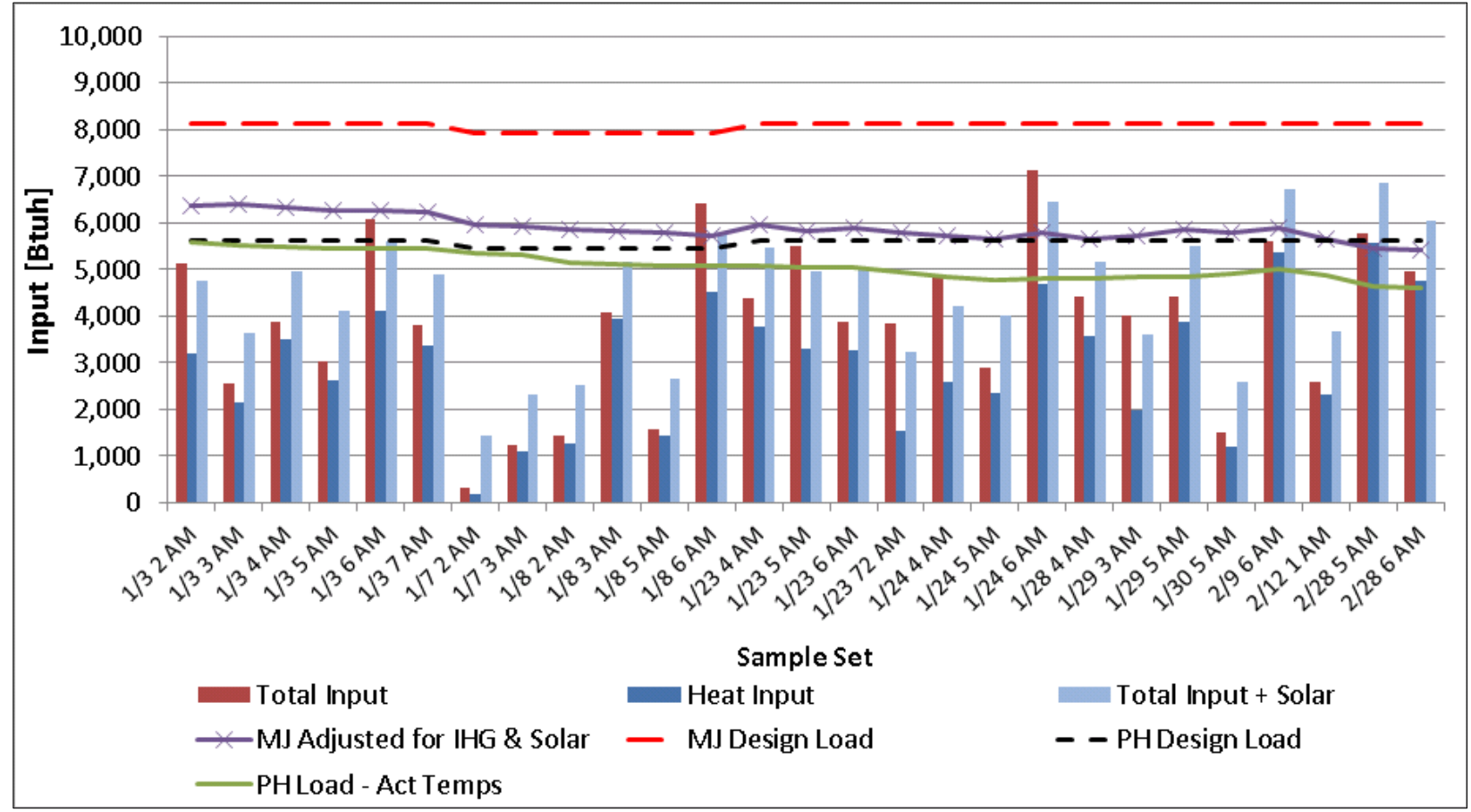

Figure 5. House 2: design loads adjusted for actual interior temperatures, interior heat gains, and solar gains compared to measured input

Because so many factors could be affecting these 1-hour periods-recovery from a deep setback, a deep setback if someone has gone away, or unusual solar gain the day before - the data were averaged for each home and are summarized in Table 3. The Total Input refers to all measured electrical energy use for each home and includes baseboard heaters, appliances, the ERV, and all miscellaneous plug loads. The Heat Input is simply the input for the electric resistance baseboards. The percent difference between the total measured energy input and the predicted loads is provided in Table 4.

Results for unoccupied House 3 were available for only a couple of periods. The monitoring on that home started several months after the first two, and hour periods where the temperature was near $0^{\circ} \mathrm{F}$ during the night were far fewer. However, the results indicate that for those periods the PHPP provides a better estimate of design loads than MJ8. A comparison of the total and heat input shows that little else was running in this home. None of the appliances were installed during the monitoring period. Without the normal internal gains from the DHW, lighting, and refrigerator to lend some heat, the predicted PHPP and actual loads are much closer.

PH sizing calculations are intended to yield designs that would provide adequate heat to the home even if it is unoccupied. Based on the limited data collected for House 3 (a currently unoccupied home) compared to the other two homes, the calculation method employed by PH appears to result in proper space conditioning. As Table 4 shows, the homes with occupants required 24\% less energy to keep the space at a temperature lower than the PH design load, even when the actual interior temperatures were used instead of the design condition. These numbers seem to indicate that gains from occupants and plug loads are more significant than anticipated and can be used in design calculations. 
Table 3. Comparing Average Modeled Design Loads With Average Measured Input

\begin{tabular}{l|c|c|c|c|c|c|c|c}
\hline & $\begin{array}{c}\text { Measured } \\
\text { Indoor } \\
\text { Temp }\end{array}$ & $\begin{array}{c}\text { Total } \\
\text { Input }\end{array}$ & $\begin{array}{c}\text { Heat } \\
\text { Input }\end{array}$ & $\begin{array}{c}\text { MJ8 } \\
\text { Design } \\
\text { Load }\end{array}$ & $\begin{array}{c}\text { PH } \\
\text { Design } \\
\text { Load }\end{array}$ & $\begin{array}{c}\text { MJ8 } \\
\text { Load - } \\
\text { Actual } \\
\text { Temps }\end{array}$ & $\begin{array}{c}\text { MJ8 } \\
\text { Adjusted } \\
\text { for Internal } \\
\text { Heat Gains } \\
\text { and Solar }\end{array}$ & $\begin{array}{c}\text { PH } \\
\text { Load - } \\
\text { Actual } \\
\text { Temps }\end{array}$ \\
\hline & ${ }^{\circ} \mathbf{F}$ & $\mathbf{B t u} / \mathbf{h}$ & $\mathbf{B t u} / \mathbf{h}$ & $\mathbf{B t u} / \mathbf{h}$ & $\mathbf{B t u} / \mathbf{h}$ & $\mathbf{B t u} / \mathbf{h}$ & $\mathbf{B t u} / \mathbf{h}$ & $\mathbf{B t u} / \mathbf{h}$ \\
\hline House \#1 & 61 & 3,613 & 2,690 & 9,059 & 5,726 & 7,994 & 6,484 & 4,729 \\
\hline House \#2 & 64 & 3,898 & 3,017 & 8,067 & 5,587 & 7,385 & 5,926 & 5,076 \\
\hline House \#3 & 67 & 5,186 & 5,120 & 7,795 & 4,874 & 7,331 & 6,291 & 4,743 \\
\hline
\end{tabular}

Table 4. Percent Difference Compared to Total Input

\begin{tabular}{l|c|c|c|c|c|c|c}
\hline & $\begin{array}{c}\text { Total } \\
\text { Input }\end{array}$ & $\begin{array}{c}\text { Heat } \\
\text { Input }\end{array}$ & $\begin{array}{c}\text { MJ8 } \\
\text { Design } \\
\text { Load }\end{array}$ & $\begin{array}{c}\text { PH } \\
\text { Design } \\
\text { Load }\end{array}$ & $\begin{array}{c}\text { MJ8 } \\
\text { Load - } \\
\text { Actual } \\
\text { Temps }\end{array}$ & $\begin{array}{c}\text { MJ8 } \\
\text { Adjusted for } \\
\text { Internal } \\
\text { Heat Gains } \\
\text { and Solar }\end{array}$ & $\begin{array}{c}\text { PH Load - } \\
\text { Actual } \\
\text { Temps }\end{array}$ \\
\hline House \#1 & - & $-34 \%$ & $61 \%$ & $37 \%$ & $55 \%$ & $44 \%$ & $24 \%$ \\
House \#2 & - & $-29 \%$ & $52 \%$ & $30 \%$ & $47 \%$ & $34 \%$ & $23 \%$ \\
\hline House \#3 & - & $-1 \%$ & $33 \%$ & $-6 \%$ & $29 \%$ & $18 \%$ & $-9 \%$ \\
\hline
\end{tabular}




\section{Discussion}

The difference between total energy and heating input in both House 1 and House 2 is due to the DHW. During periods when the DHW is replenishing standby losses, House 2's DHW energy use averages about $500 \mathrm{~W}$; House 1's tank averages about $200 \mathrm{~W}$. However, the tank in House 1 replenishes losses every 2-3 hours and the tank in House 2 runs every $4-5$ hours. Therefore, the spikes in input should not be assumed to happen every hour. Differences could be due to tank temperature sensors and settings. If the DHW loads are averaged based on the number of times they replenish during the night, the profiles look similar to those in Figure 6 and Figure 7. Average energy use from DHW is $81 \mathrm{~W} / \mathrm{h}$ and $83 \mathrm{~W} / \mathrm{h}$ for House 1 and House 2, respectively.

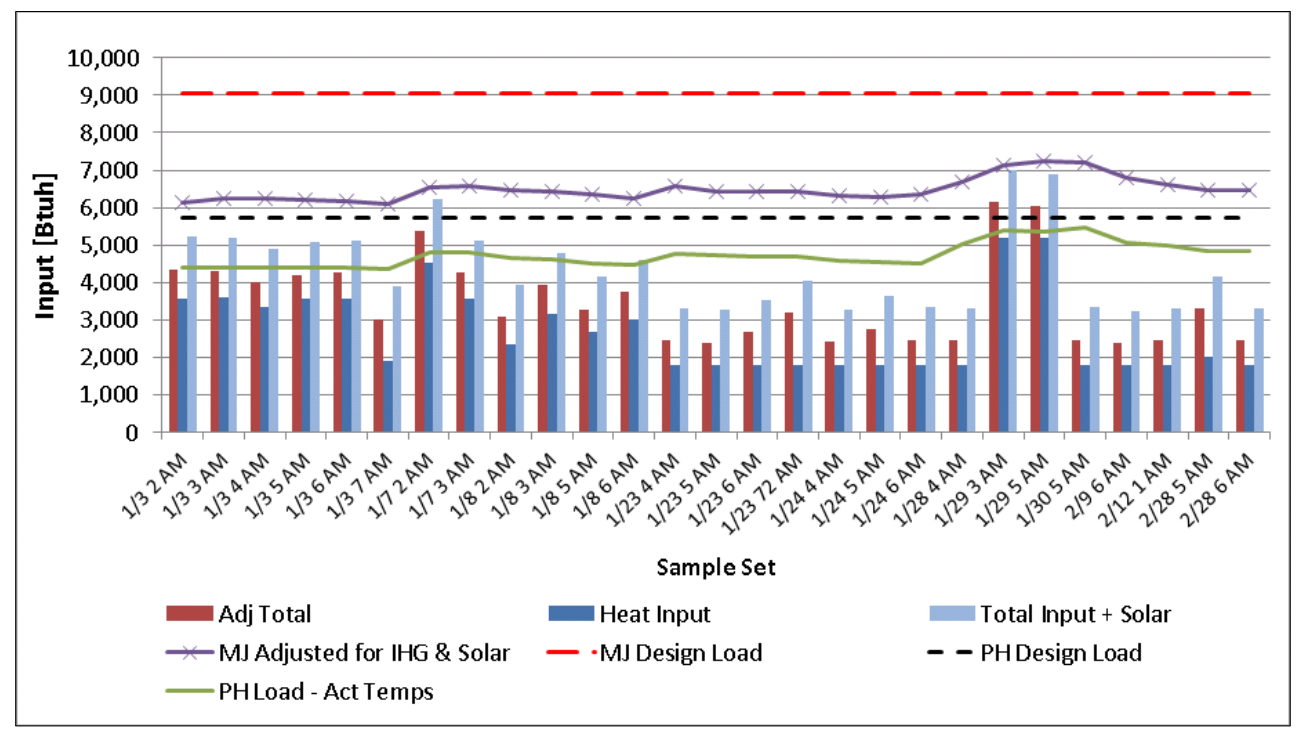

Figure 6. Predicted design loads for House 1 compared to total input adjusted to reflect average DHW energy use from standby losses

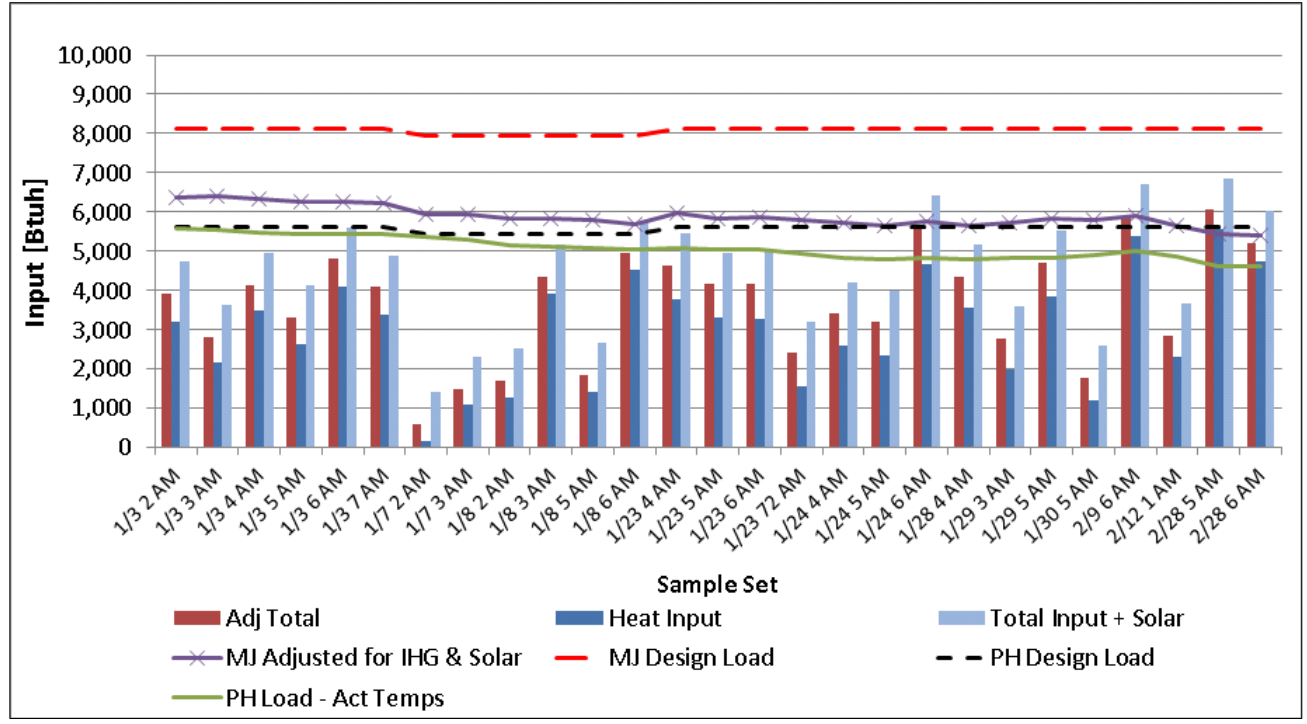

Figure 7. Predicted design loads for House 2 compared to total input adjusted to reflect average DHW energy use from standby losses 
The spikes in total and heating energy use in the two periods on January 29 for House 1 coincide with an increase in thermostat settings because the homeowner had company for 2 days (Figure 8). The thermal inertia of the buildings would be expected to cause a spike in heating energy use to recover from a period of setback. Excess energy is needed to bring the building up to temperature and meet the load.

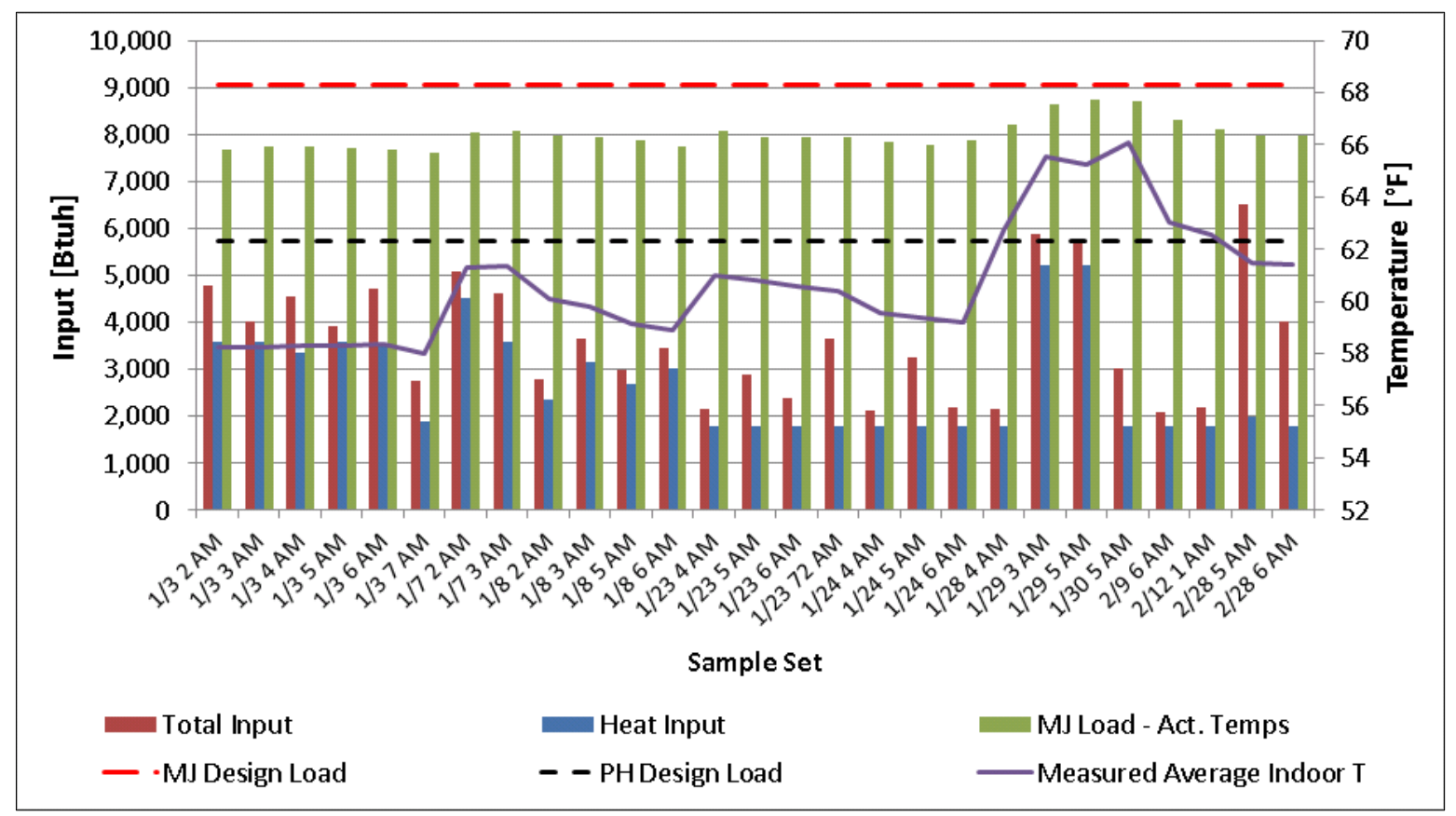

Figure 8. Design loads and measured input for House 1 compared to average indoor temperature

House 1 also experienced an extreme spike in total energy use on February 28, which seems to be due to shower use - the bathroom heater was also running during that period just before the DHW energy use began. Typical tank replenishment for this home generally takes 4-5 minutes but the water heater ran for 15 minutes during that period.

In Figure 9, the spike in indoor air temperature for House 2 on January 7 is a result of the thermostat being turned up a few hours before the data period shown. Several of the baseboard heaters were running; a closer look at the data for several hours before shows the temperature being brought up a few degrees. The thermostats were then turned back down, which resulted in the very low level of energy use in the following hours. 


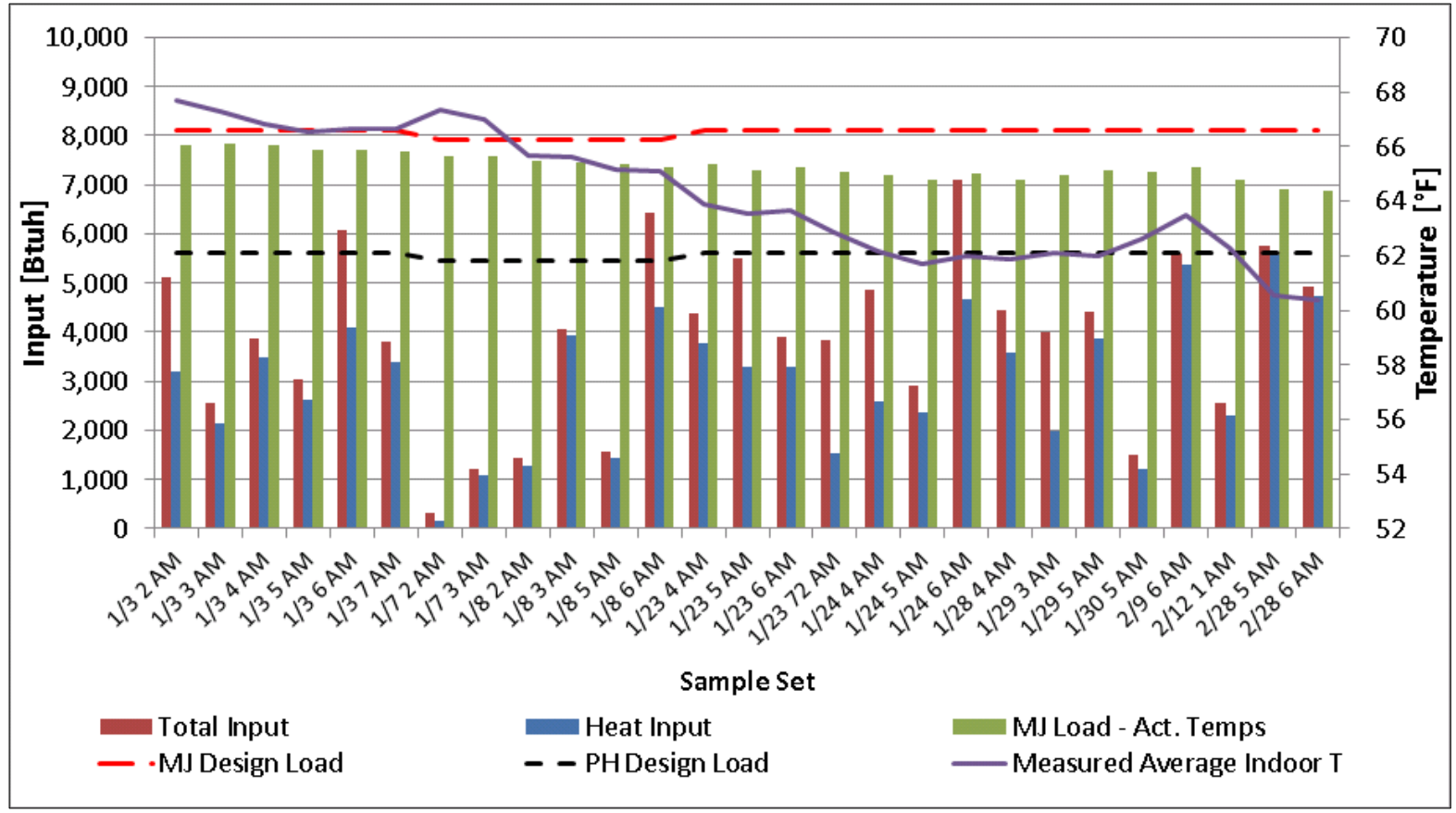

Figure 9. Design loads and measured input for House 2 compared to average indoor temperature

\subsection{Recommendations for Sizing Heating Equipment for Superinsulated Buildings}

Although the data from this study are very limited, they clearly suggest — for the homes testedthat calculating design heating loads for superinsulated homes should include some level of internal gains and the effects of thermal inertia. Results show that the total energy input into the space was far lower under design conditions than predicted using recommended ACCA MJ8 design assumptions. Even the PHPP design load predictions exceeded the total input by more than $24 \%$ in the occupied homes.

At this time, CARB is unaware of another design load calculation method or tool other than the PHPP that is specifically intended for use with superinsulated structures. Appendix B includes a guide that provides shortcuts to using that software to obtain peak design loads. 


\section{Conclusions and Lessons Learned}

How do the design loads calculated using MJ8 and PH methods compare to the measured peak building loads?

The applicability of current mechanical equipment sizing methods for superinsulated homes was investigated. Based on data collected for three homes, the PHPP assumptions and methods for sizing equipment appear to be far better suited to these types of homes than ACCA's MJ8. For the two occupied homes, MJ8 calculations resulted in loads that are an average of $56 \%$ higher than actual measured design loads; PHPP calculations resulted in loads that were $34 \%$ higher on average.

If the modeled loads are significantly different from the actual loads, can the differences be explained?

Unlike MJ8, the PHPP software takes thermal inertia into account along with solar gains - and other internal gains from occupants and equipment - when calculating the design heating load. This results in a significantly lower design load than MJ8 predicts.

Interior temperatures were also kept lower than design assumptions in both homes. If actual interior temperatures are considered, MJ8 differences are reduced to 51\% larger than actual and PHPP results are 24\% larger on average.

What recommendations can be made about heating equipment sizing for superinsulated buildings?

Based on these results, CARB recommends that internal and solar gains be included and some credit for thermal inertia be used in sizing calculations for superinsulated homes. Doing so results in a much closer approximation of the building's design load and still provides a slight safety margin. 


\section{Next Steps}

The results of the study clearly indicate that the PHPP method for calculating design heating loads is more appropriate than MJ8 for superinsulated buildings; however, the data set is clearly limited to small, single-family detached, or duplex homes. A wider array of house sizes and climate zones will need to be studied before recommendations for widespread use of that sizing tool are made.

A simpler tool that uses these principles would be very helpful to those who are performing sizing calculations. Even though the PHPP is available to anyone who wishes to use it, weather files can be limited and takeoffs are cumbersome. A more automated tool with a greater variety of data files would be extremely useful. 


\section{References}

Air Conditioning Contractors of America (ACCA). 2009. "Manual J8, Residential Load Calculations." Third Edition, V. 1.00. ACCA, Arlington, VA.

Feist, W. (2007). Passive House Planning Package: Requirements for Quality Approved Passive Houses. PHI-2007/1(E). Urbana, IL: Passive House Institute US. 


\section{Appendix A: Software Limitations}

\section{Manual J8-Foundations}

When calculating the heat loss of slab-on-grade foundations using MJ8, an F-value is selected from a table based on vertical, horizontal, or complete slab insulation with R-values ranging from R-0 to R-15. If the R-value of a slab-on-grade foundation exceeds R-15 or the insulation configuration differs from those given the user must calculate a custom F-value.

The following steps are taken to calculate the F-value for the heat loss to a typical slab-on-grade foundation (ACCA 2009). Figure 10 illustrates the inputs needed.

1. Maximum radius considered (ft) $=\quad \mathrm{R}_{\max }=\quad$ Slab width $\div 2$

2. Radii considered ( $\mathrm{ft}$ )

$=\mathrm{R}=1 \mathrm{ft}, 2 \mathrm{ft}, 3 \mathrm{ft} \ldots \mathrm{R}_{\max }$

3. Soil path length ( $\mathrm{ft}$ )

$=\quad \mathrm{SPL}=$

$3.14 \times \mathrm{R}-1$

4. Soil path R-value $\left(\mathrm{ft}^{2}-^{\circ} \mathrm{F}-\mathrm{h} / \mathrm{Btu}\right)=\mathrm{R}_{\text {soil }}=$

$\mathrm{R}$ per foot soil $\times \mathrm{SPL}$

5. Effective path $\mathrm{R}$-value $\left(\mathrm{ft}^{2}-{ }^{\circ} \mathrm{F}-\mathrm{h} / \mathrm{Btu}\right)=$

6. Effective path $\mathrm{U}$-value $\left(\mathrm{Btu} / \mathrm{ft}^{2}-{ }^{\circ} \mathrm{F}-\mathrm{h}\right)=$

7. $\mathrm{F}$-value $\left(\mathrm{Btu} / \mathrm{ft}-{ }^{\circ} \mathrm{F}-\mathrm{h}\right)=\mathrm{F}_{\text {value }}=$ for each foot up to the maximum radius

$\mathrm{R}_{\mathrm{Eff}}=\mathrm{R}_{(\text {air-to-air) }}$ material $+\mathrm{R}_{\text {soil }}$

$\mathrm{U}_{\mathrm{Eff}}=1 \div \mathrm{R}_{\mathrm{Eff}}$

$\mathrm{F}_{\text {value }}=\quad$ sum of the effective path U-value

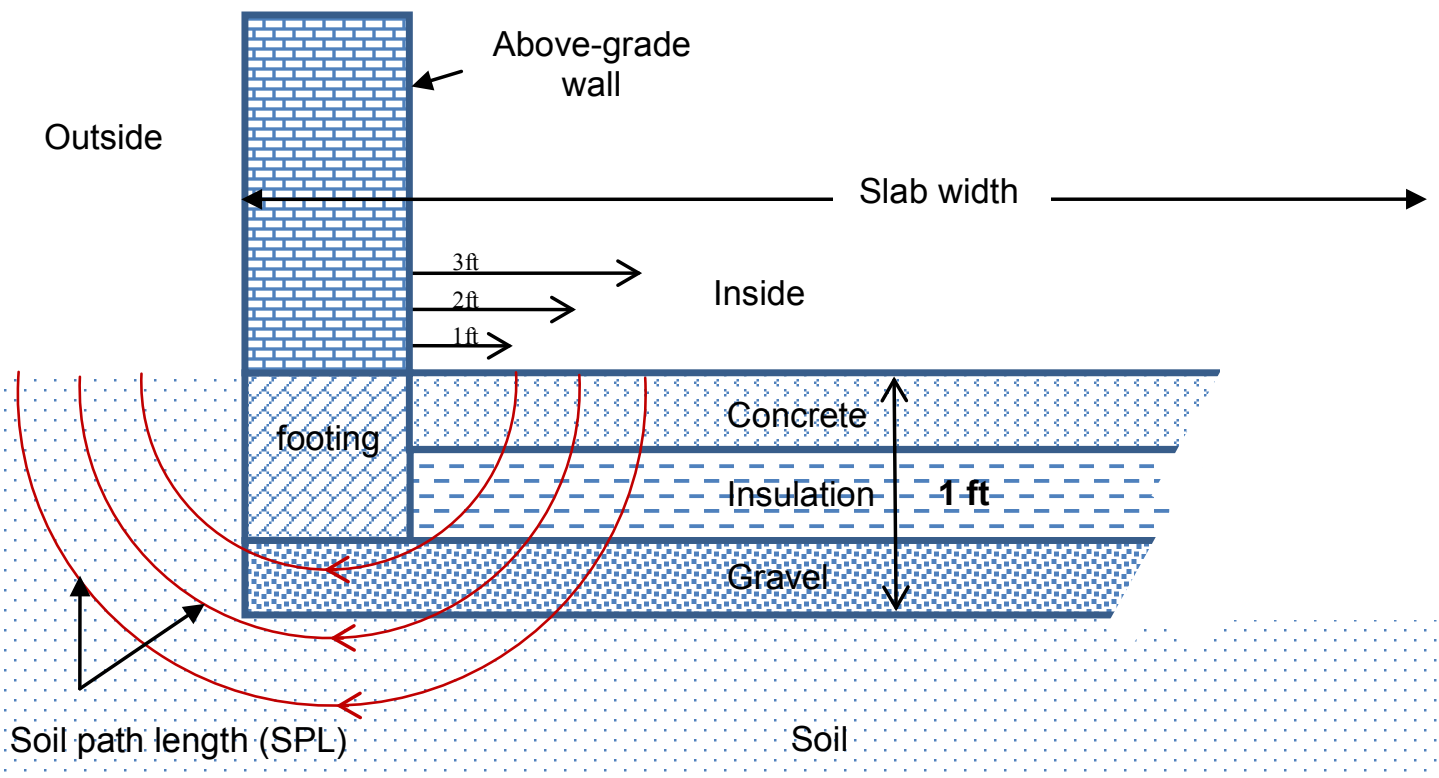

Figure 10. Sketch of construction detail of slab-on-grade foundation

\section{Manual J8-Building Components}

For ease of use, programs such as Wrightsoft's Right-Suite Universal 2015 have incorporated radio buttons to allow the user to input building components by selecting options to build an 
assembly visually (see Figure 11 for an example). Although this feature can expedite defining building components, it is often not appropriate for higher performing dwellings. The issue is that even though the software allows numerous options to be selected in each category that comprises the wall assembly per MJ8 requirements, the final assembly used in the load calculation is based on the closest available building assembly found in Table 4A of MJ8.

In Figure 11, a typical $2 \times 6$ wall assembly is input but an additional R-10 of exterior rigid insulation is added (see the Results in the upper right corner of Figure 11). It shows the Unominal based on the buttons selected by the user and below that shows the MJ8 Code (referring to an assembly in Table 4A) and MJ8 U-value. In this case the U-nominal is $0.036 \mathrm{Btu} / \mathrm{h} / \mathrm{ft}^{2}-{ }^{\circ} \mathrm{F}$ and the MJ8 U-value is $0.048 \mathrm{Btu} / \mathrm{h} / \mathrm{ft}^{2}-{ }^{\circ} \mathrm{F}$. This is a $25 \%$ reduction in the performance of the wall assembly.

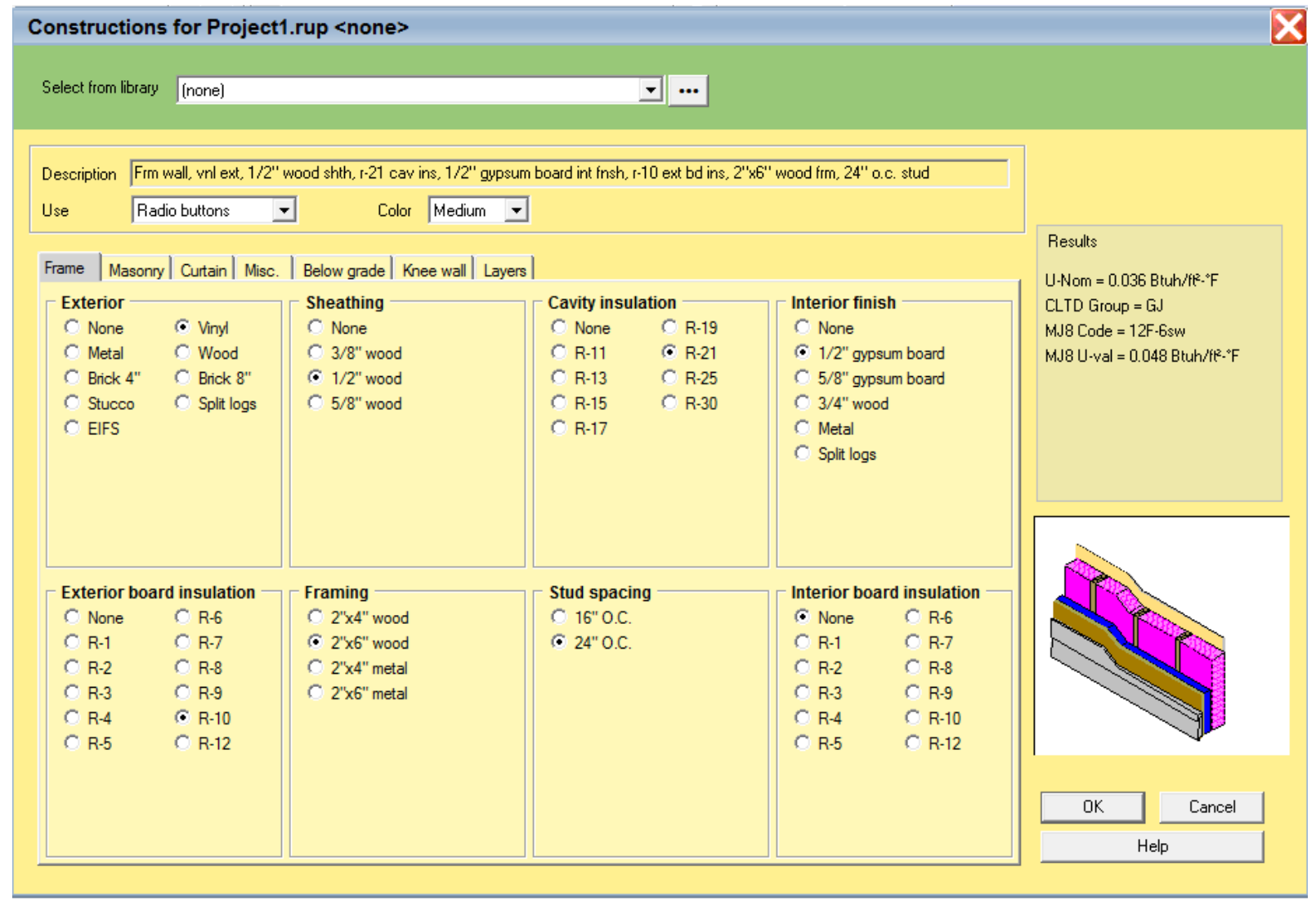

Figure 11. Screen shot of radio button input of the above-grade wall assembly with exterior rigid insulation in Wrightsoft software

Even if the exterior rigid insulation is removed from the wall assembly (see Figure 12), the difference between the U-value input and that used in the MJ8 analysis is $12 \%$. Therefore, CARB recommends using the radio button feature to calculate the U-nominal value and then inputting this as a custom value. Even with this method, a cooling load temperature difference Group code would need to be specified (refer to Manual J8 A12-11 to -19). Alternatively, the wall assembly can be defined with custom layers that use a parallel-path heat transfer calculation method. 


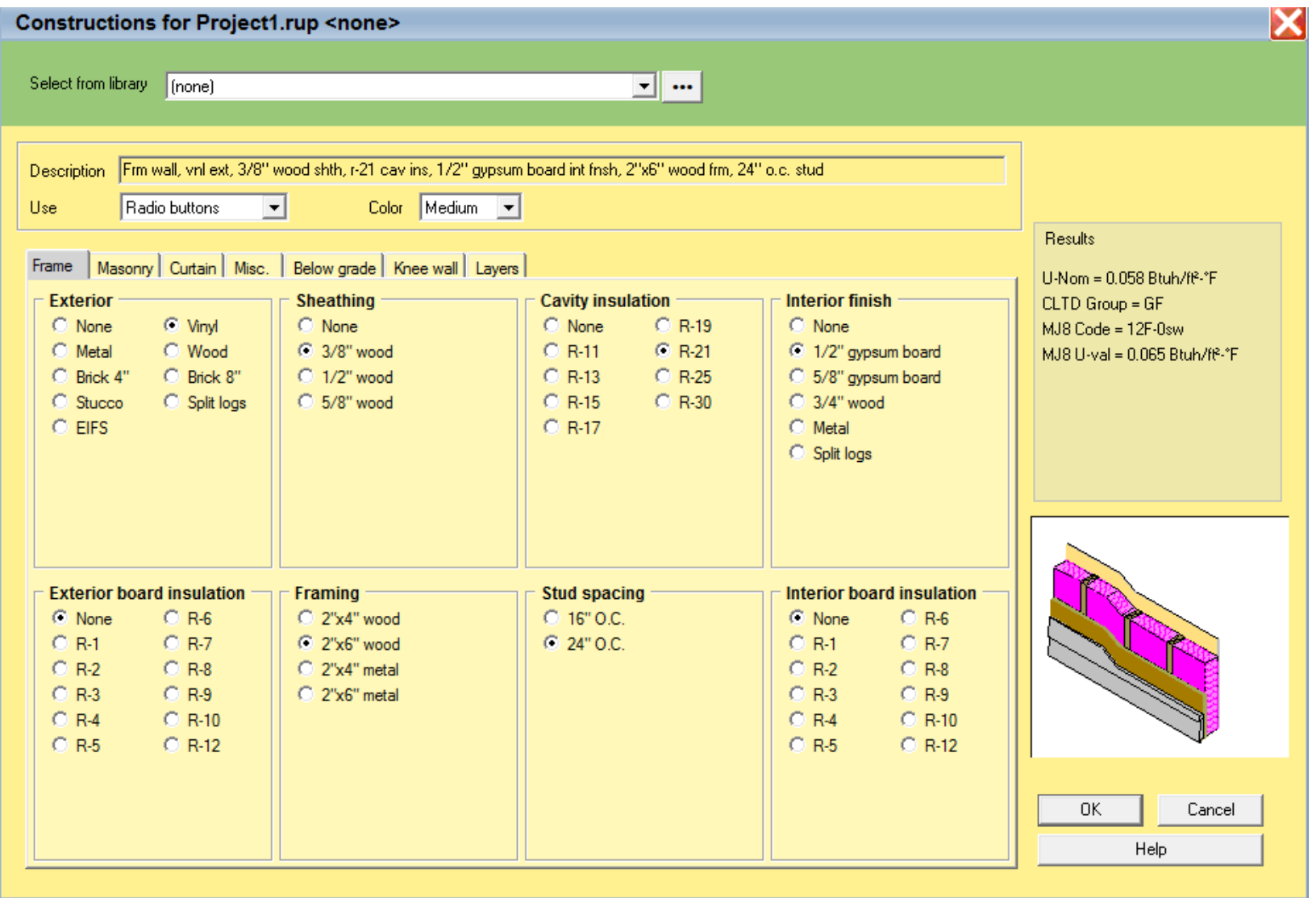

Figure 12. Screen shot of radio button input of the above-grade wall assembly without exterior rigid insulation in Wrightsoft software 


\section{Appendix B: Using the Passive House Planning Package To Calculate Design Heating Loads}

The research that supports these recommendations evaluated only one design load calculation method (PHPP) that is intended for use with superinsulated structures. This tool can be acquired at http://www.passiv.de/en/04 phpp/04 phpp.htm. The following flowchart outlines the key steps in performing these calculations.

\section{Progression Summary}

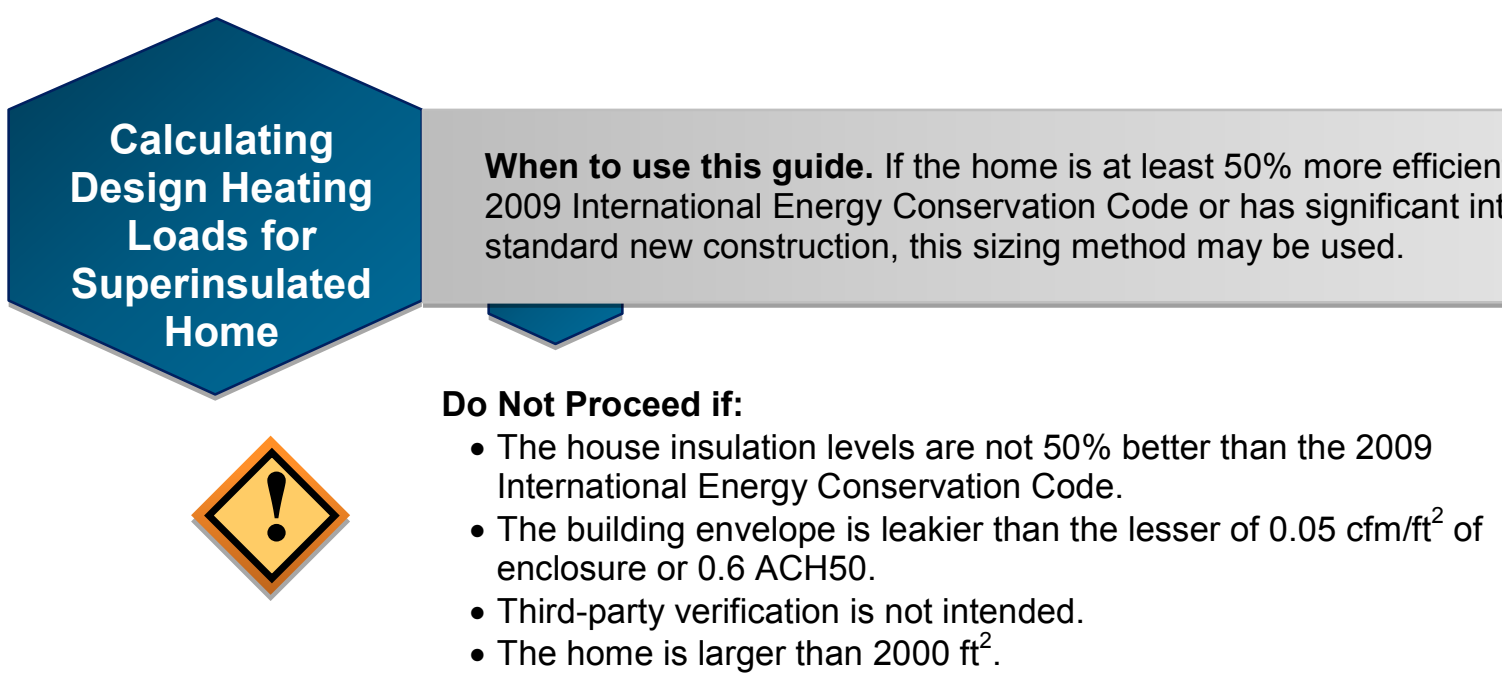

Envelope Loads. Use the building insulation levels, window efficiencies, mechanical ventilation rates, and infiltration rate to calculate the envelope heating load.

Calculate the Envelope Heating
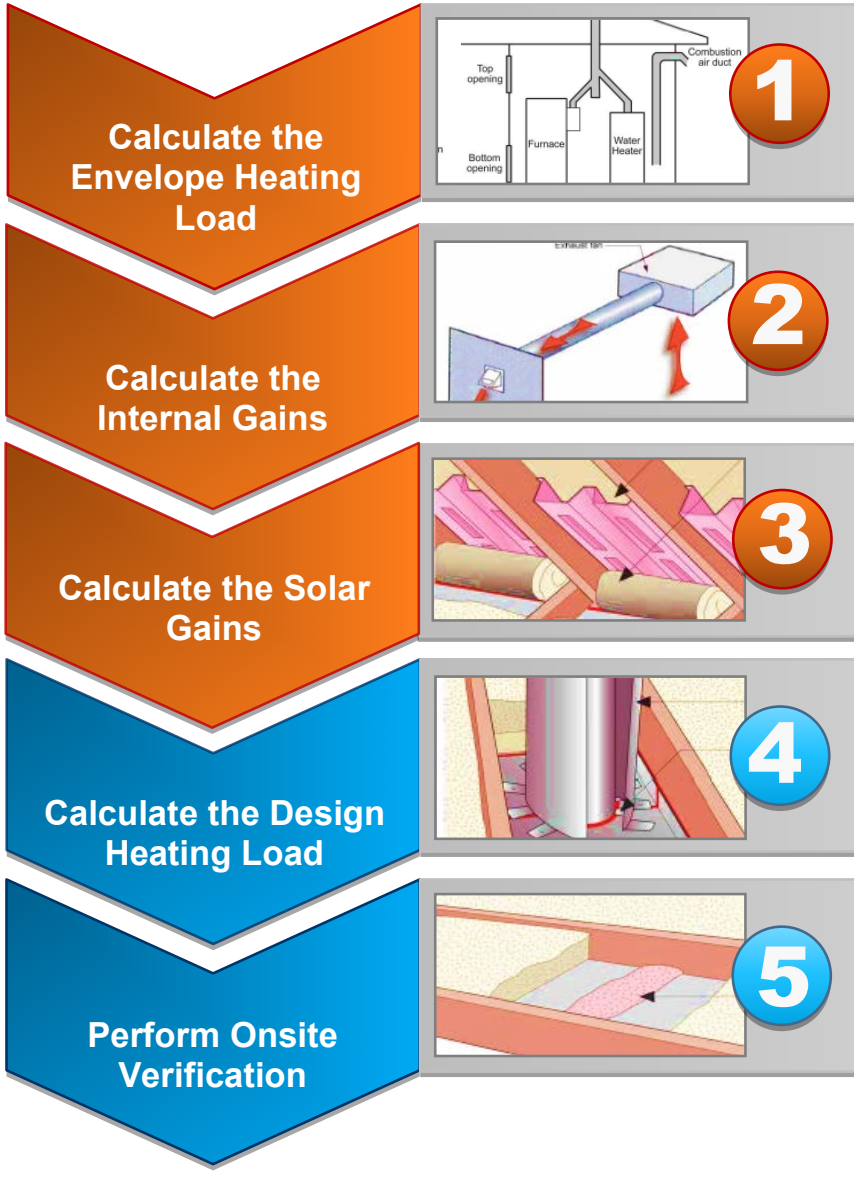

Gains From People and Appliances. In a superinsulated home, gains from people and equipment can significantly offset the heat required in the space; the smaller the load, the bigger the effect.

\section{Internal Gains}

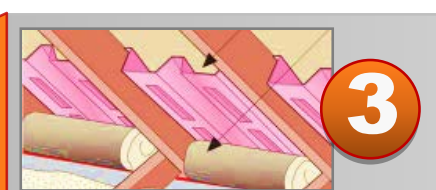

Solar Gains. The energy provided by the sun can help offset the heat needed for hours in a superinsulated airtight home.

Gains

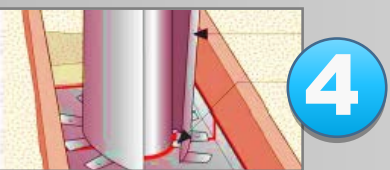

Determine the Total Heat Load. To obtain the design heating load for a superinsulated home, subtract the internal and solar gains from the envelope load.

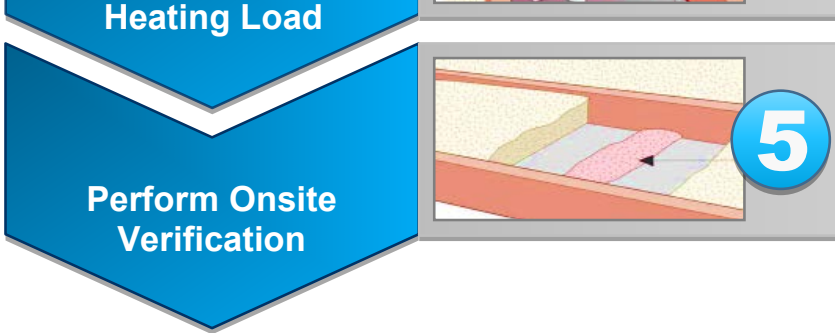

Verify Efficiency Levels. Insulation levels, air leakage, and duct leakage must be verified to match the values used in the sizing calculations. 


\section{Passive House Planning Package Inputs}

As mentioned in the main body of the report, this method relies on the evaluation of two distinct design conditions under which the peak design load could occur:

- Weather Condition 1: a cold but sunny winter day with a cloudless sky (high-pressure weather situation) or

- Weather Condition 2: a moderately cold but overcast day with minimal solar radiation (Feist 2007).

Which condition will result in the highest load depends on the orientation of the home, the number of windows, the SHGC, etc. Thus, CARB recommends that the PHPP software be used to generate the heating design loads. Individual rooms can also be analyzed to aid in the sizing and design process. Climate files have been specifically developed for this analysis; numerous sites are available for download. Several shortcuts can be taken without compromising the design calculations. Figure 13 shows the tabs from the PHPP v8.5 that should be filled out for design heating load calculations.

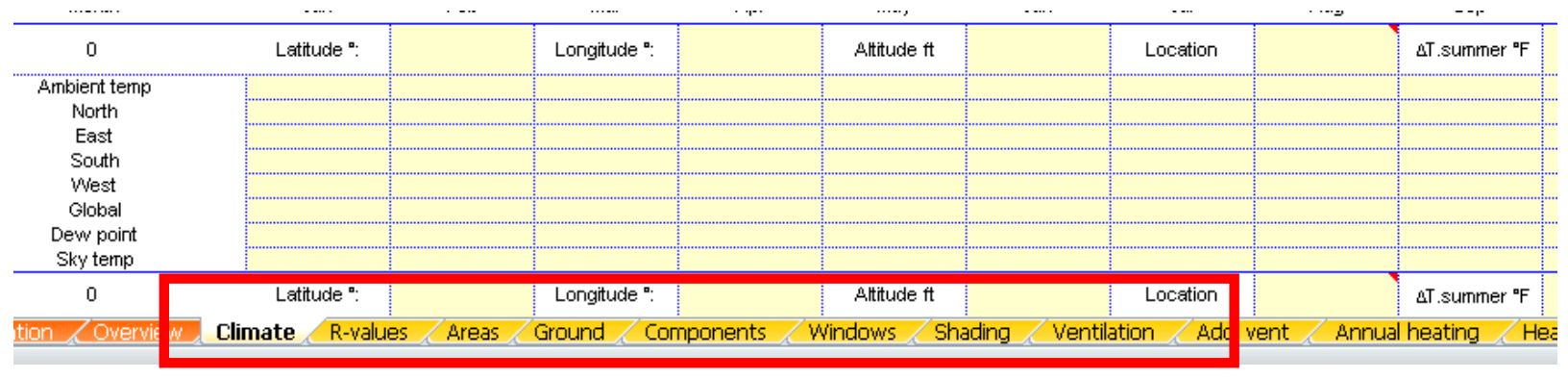

Figure 13. Tabs in the PHPP that should be filled out for design heating load calculations

The following sections suggest shortcuts to using this software if $\mathrm{PH}$ certification is not desired.

\section{Climate}

Because the temperatures of the interior surfaces of the building envelope are warmer and superinsulated buildings have few drafts, thermostat set points can be kept lower than in typical construction and still provide the desired comfort levels. Thus, the interior design temperature used in the PHPP is $68^{\circ} \mathrm{F}$ instead of the standard $70^{\circ} \mathrm{F}$ setting that is typically required. This value can be overridden on the Verification tab; however, this is not recommended

Figure 14 is a screen shot of the Climate Data tab on which the location is identified. The weather data automatically populate when the location is selected. If the location needed is not shown in the drop-down list in the upper left corner of the screen, a data file can be generated by visiting the Passipedia website at http://passipedia.org/start. Chose "Tools/PHPP" from the menu list on the left side of the screen to see an option for using the climate tool.

\section{$\underline{\text { Ensuring Success }}$}

Climate data can be found here http://passipedia.org/planning/calculating_energy_efficiency/phpp_- the passive_house_planning_package/climate_data_tool 


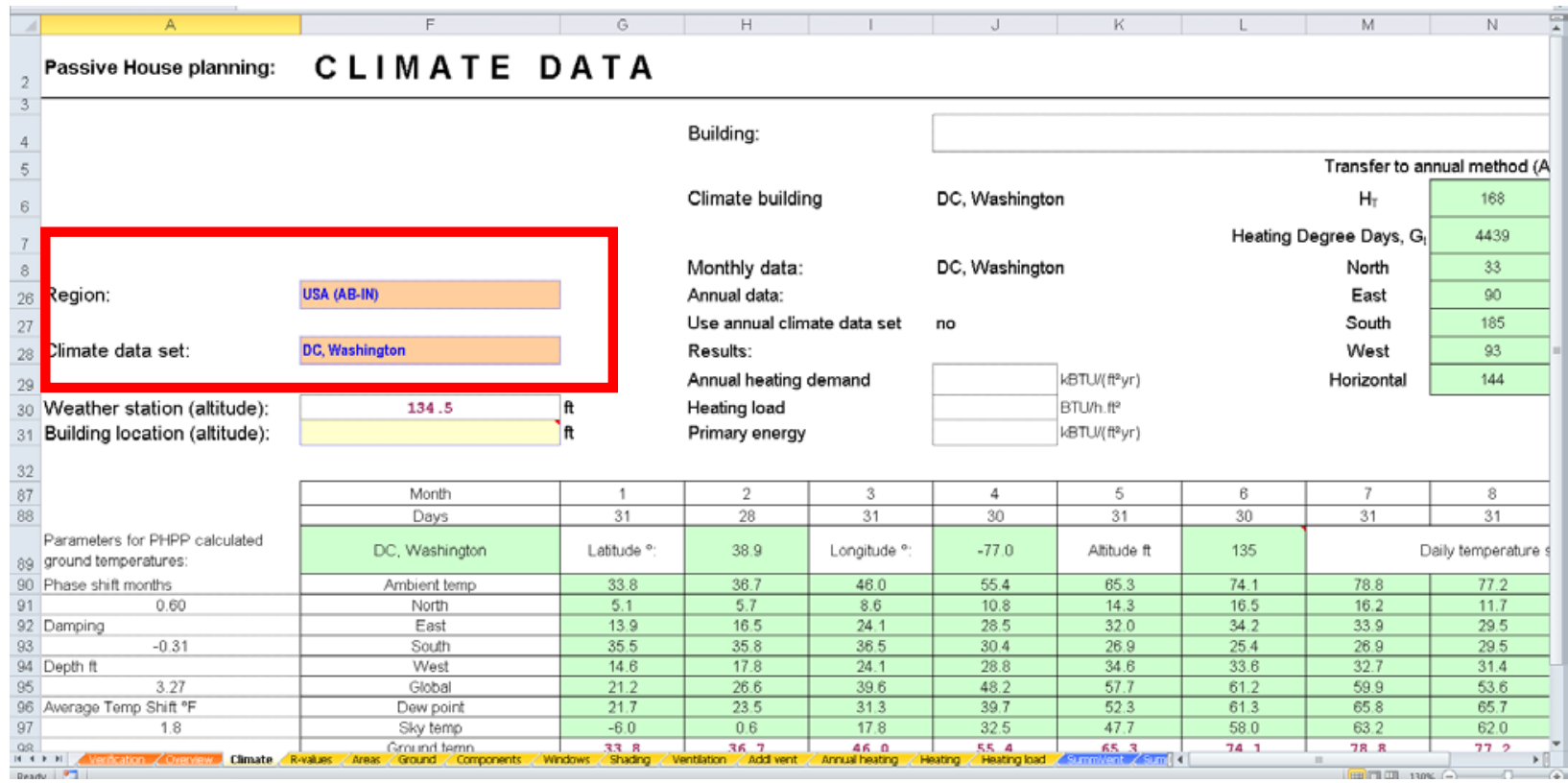

Figure 14. Climate data screen from the PHPP

The two design heating conditions are shown on the right side of the weather data table (Figure 15). The two temperatures evaluated in the PHPP are derived through simulations. Unless the weather files for the PH software were obtained, this method should not be used. The modeling exercise needed to determine these values is outside the scope of this report. Fortunately, these files are not expensive and the database of climate sites is very extensive.

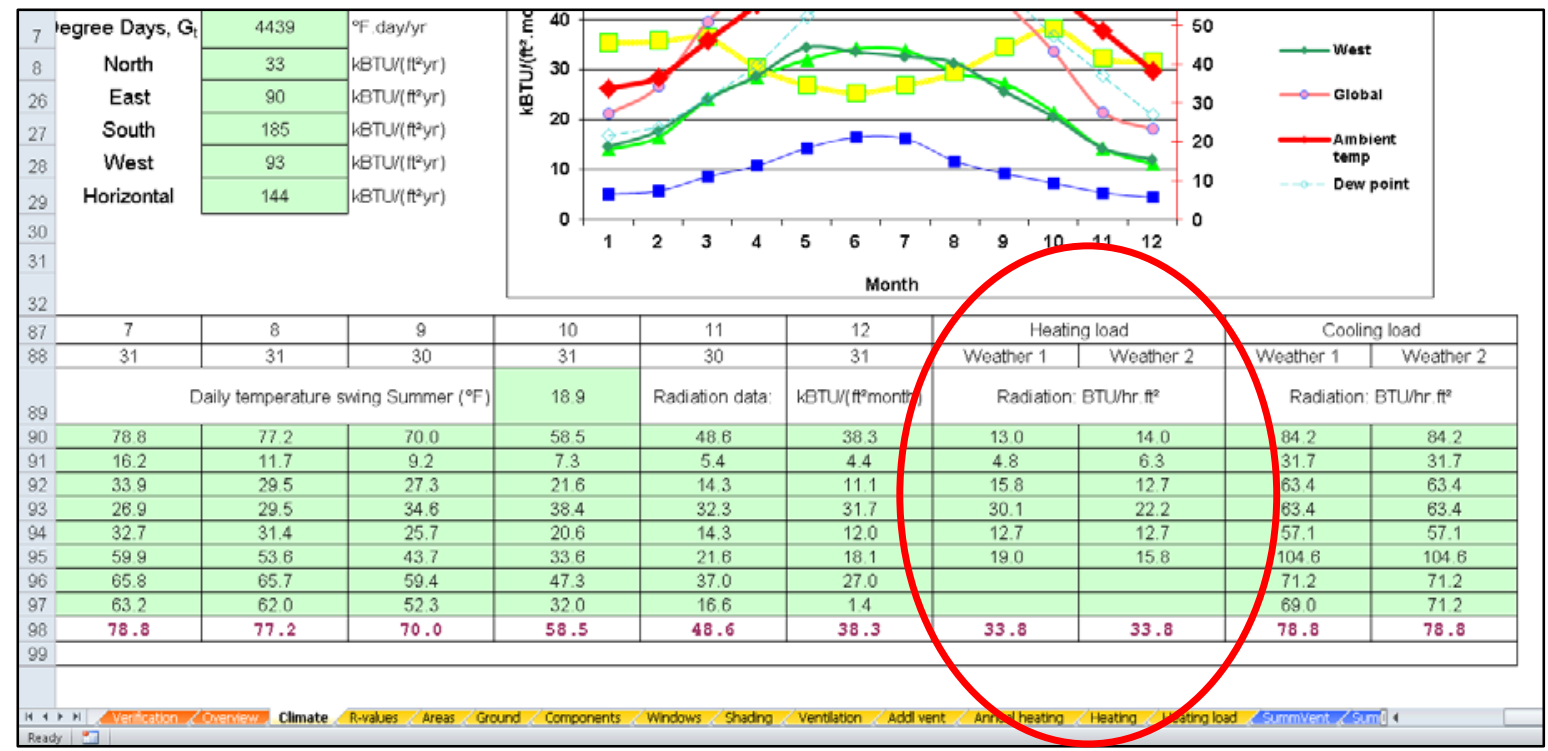

Figure 15. Screen shot showing the two different design conditions to be evaluated for this site 


\section{R-Values}

The efficiency information for each building component is typically entered for each layer in the assembly. However, if the overall R-value of each of assembly is known, simply enter information on the first line for each building assembly (see Figure 16). If you are certain that the overall assembly R-value would be R-40, simply state that in the first line. If thermal bridging and framing factors are of concern, take the time to enter each element of the assembly and the software will automatically calculate an overall R-value.

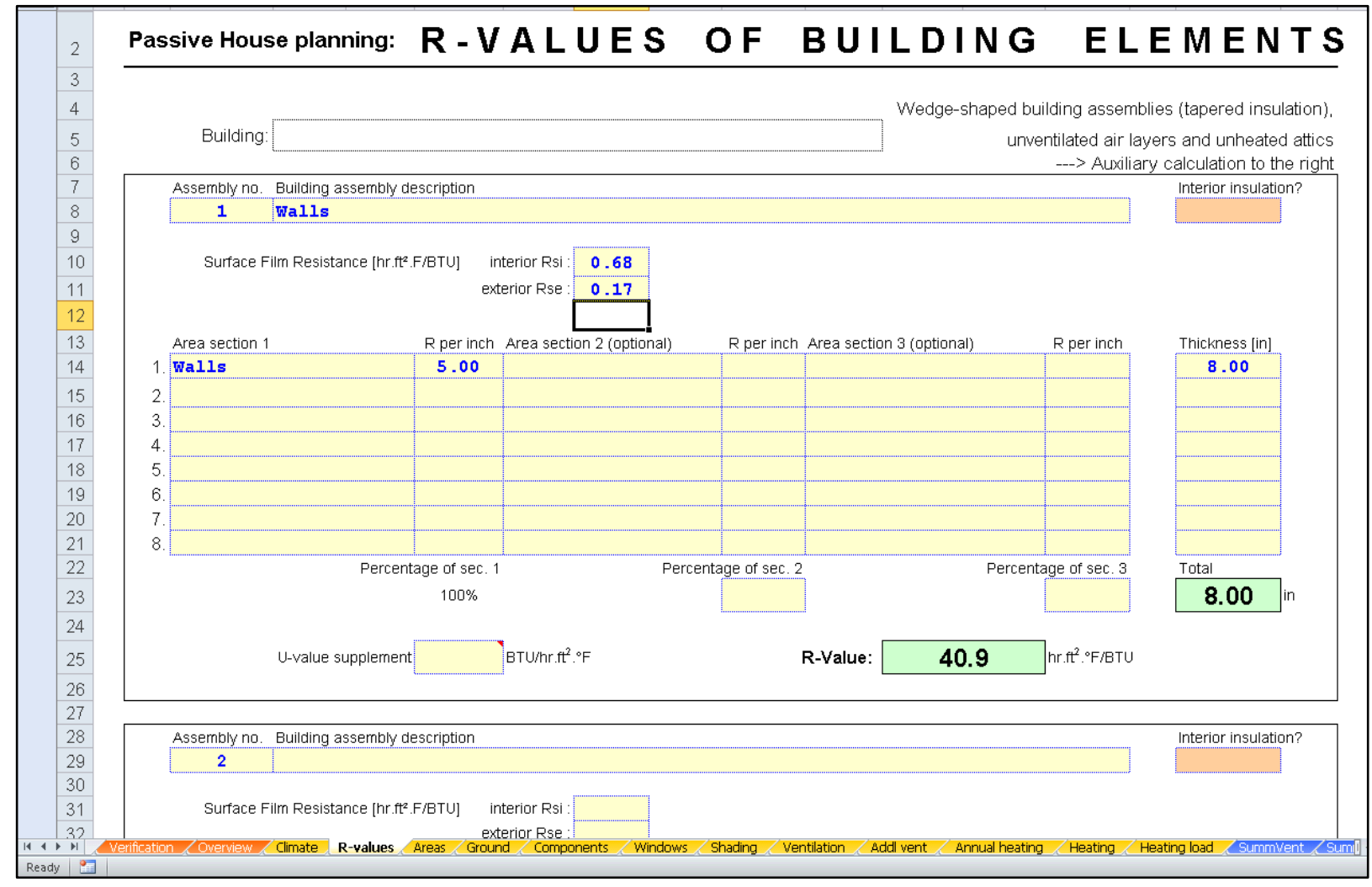

Figure 16. Enter only the top line of each assembly section to save time.

\section{Areas Tab}

Typical practice for $\mathrm{PH}$ calculations is to enter the extreme outer dimensions of each element. For example, the wall height is typically measured from the bottom of the slab insulation to the top of the ceiling insulation. Thermal bridge calculations are then performed on the intersections to determine if an energy credit or debit is needed for those areas. For this purpose, enter typical assembly dimensions with the caveat that this is a well-designed and thermal-bridge-free assembly. Any question about this warrants further investigation with a qualified consultant.

The first step is to enter your wall areas for each orientation. Window orientation is determined by referencing the appropriate wall entered on the Areas tab; therefore, the walls must be separated by orientation. 
In Figure 17, the north wall has been entered for a two-story building (assuming 8-ft ceiling heights and a 1-ft tall rim joist). To the very right of the figure, a drop-down box allows the user to select the assemblies entered on the R-values tab.

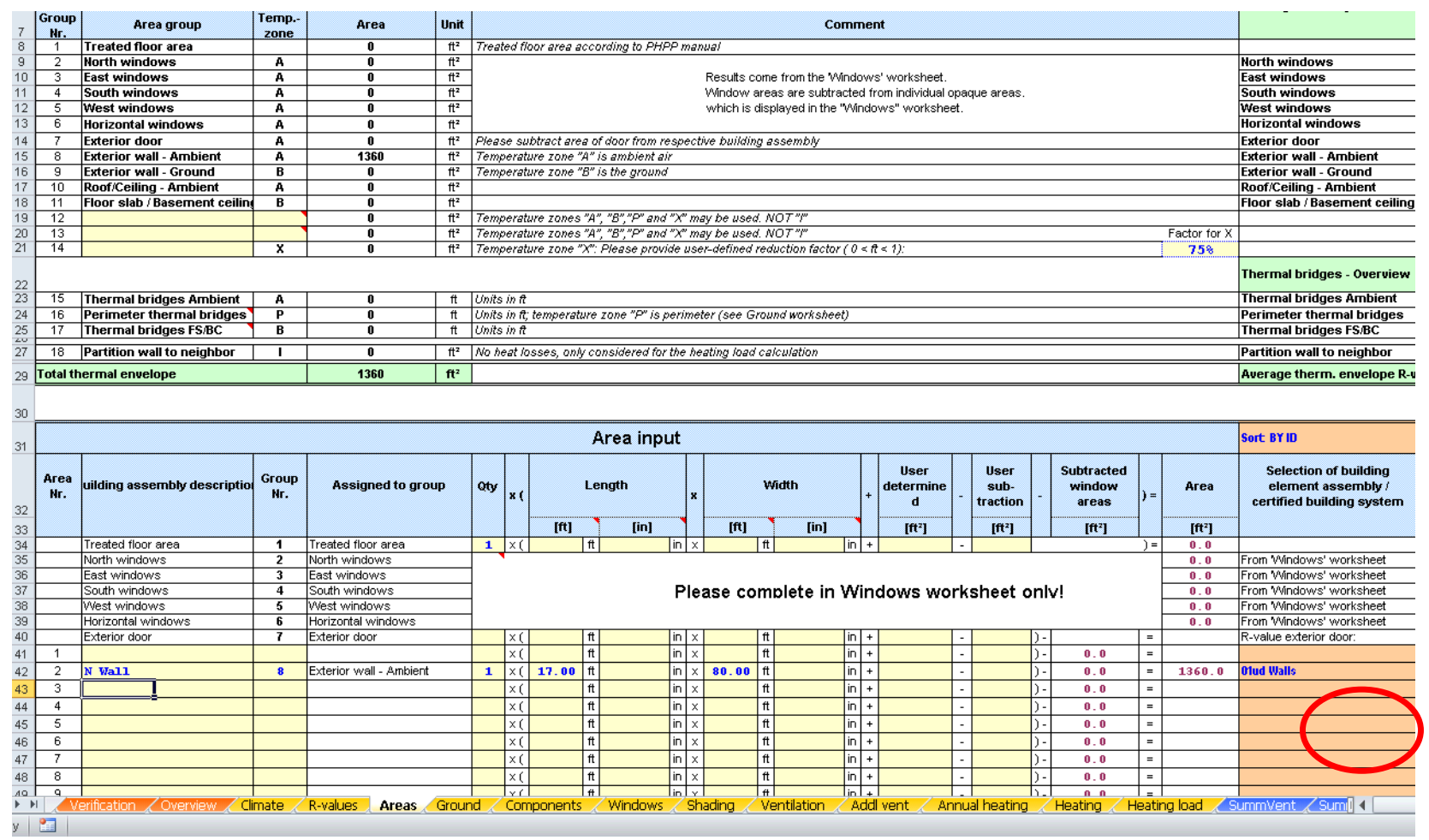

Figure 17. Example of a north wall entry on the Areas tab

Orientation of the walls is determined by specifying the deviation from north and the angle of inclination from the horizontal (see Figure 18).

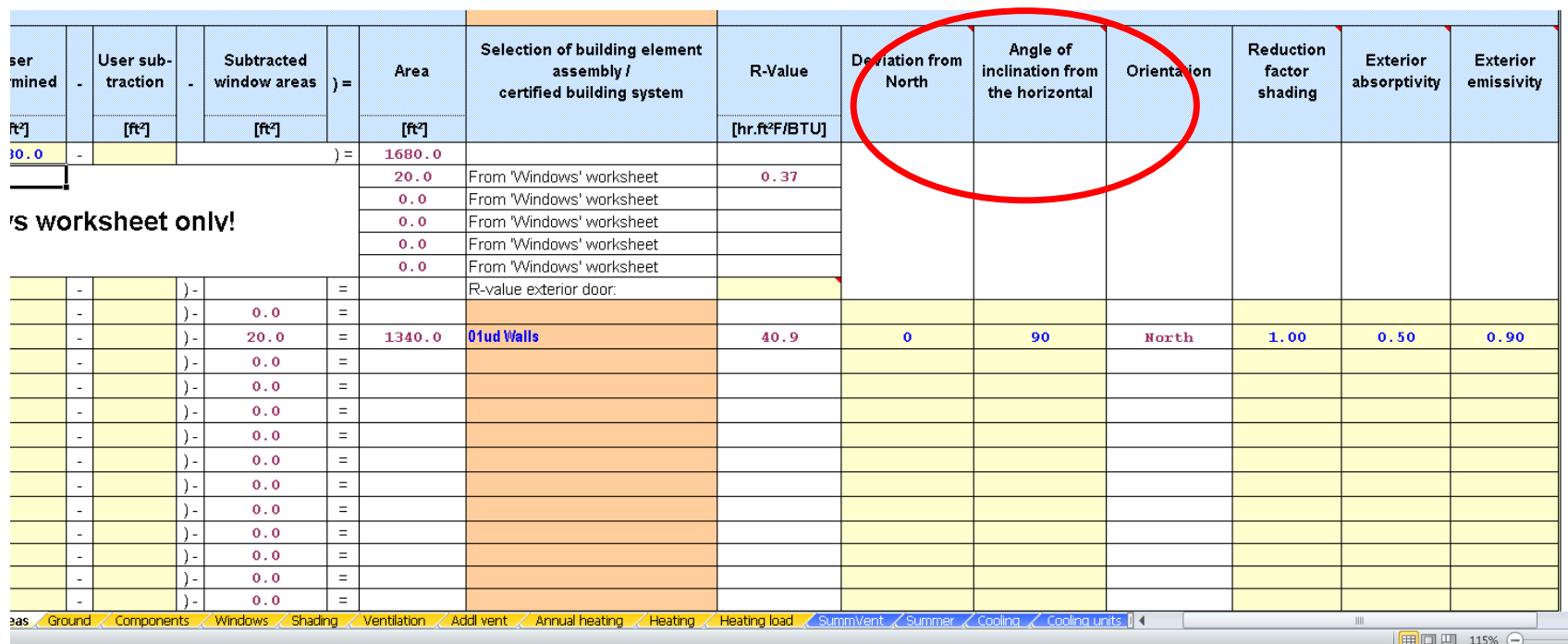

Figure 18. Example of a north wall orientation on the Areas tab 
Continue entering building assemblies until the entire thermal envelope is accounted for.

Windows will automatically be subtracted when that information is filled in. If the building has a slab-on-grade foundation and both the slab edge and under slab will be insulated, enter the insulation under the slab on this screen.

\section{Ground}

This tab is used to evaluate the effects of ground coupling on the energy use of the home. Foundation type and any intended slab edge insulation are identified on this screen. Several of these fields can be linked back to the Areas and R-values tabs. A few are highlighted in Figure 19.

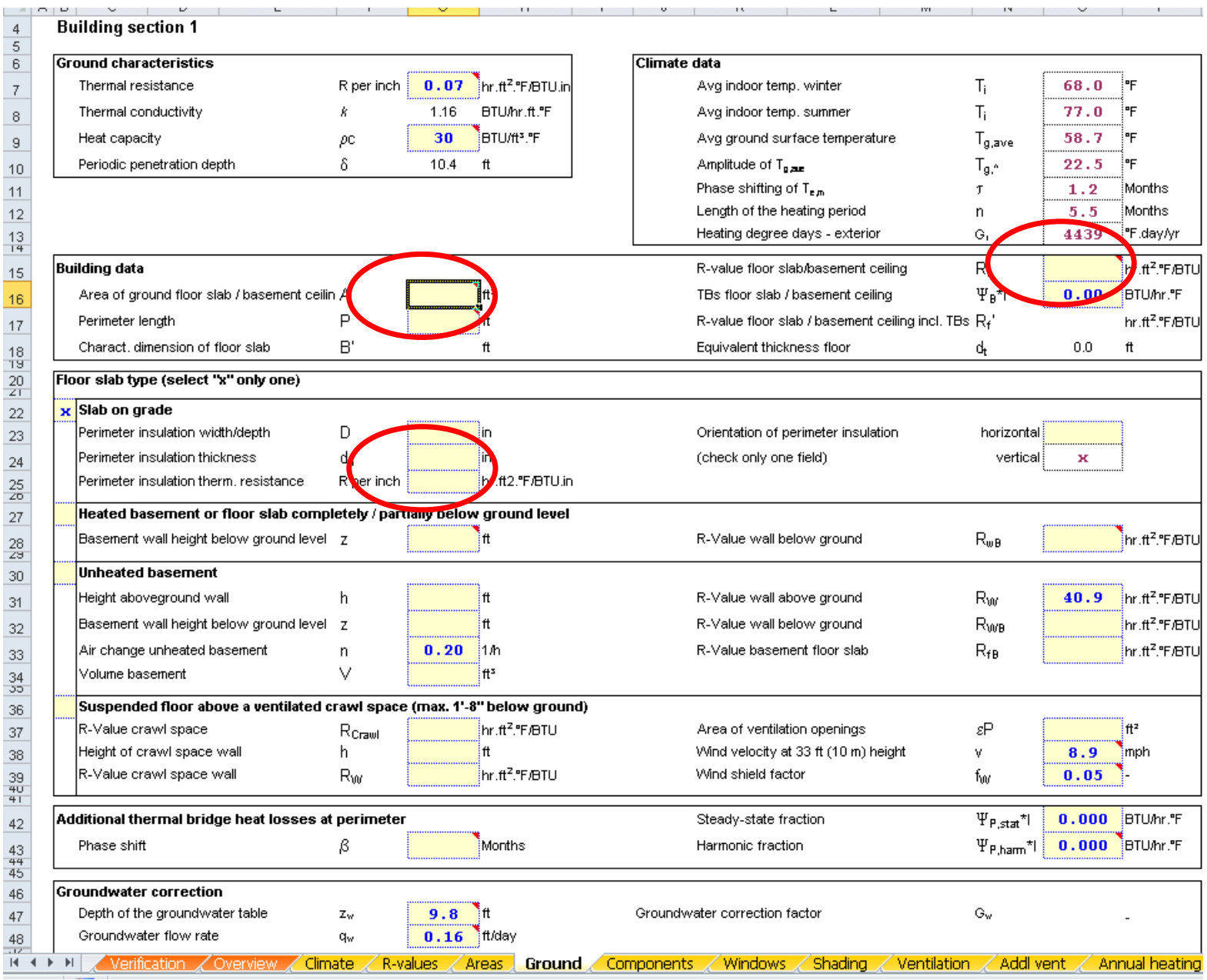

Figure 19. Several ground sheet entries can be linked to the Areas and R-values tabs

\section{Components}

This sheet contains information about a multitude of PH-certified building components, including building assemblies, windows, and mechanical ventilation equipment. If a component being selected for a project is available on the list, no further work is necessary on this page (scroll down to see available selections). If, for example, a non-PH-rated window will be used on the project, the data must be entered on this sheet. The data will then be available for selection on the other applicable sheets such as the Windows tab and the Areas tab. Accuracy on this page is 
imperative for the design load calculations. U-values of the glazing and of the frame are necessary inputs as are the thermal bridge of the frame and the installation. These values are available for many triple-pane windows manufactured outside the United States even if they are not PH certified. If these data cannot be obtained from the window manufacturer, several generic options are available.

\section{Windows}

Because solar gain is used to offset the design heating load, accuracy is crucial in these sections of the spreadsheet. Indicate the quantity and size of the windows for each wall orientation entered on the Areas tab. Select glazing type, frame type, and wall orientation from drop-down lists in the center of the page (Figure 20).

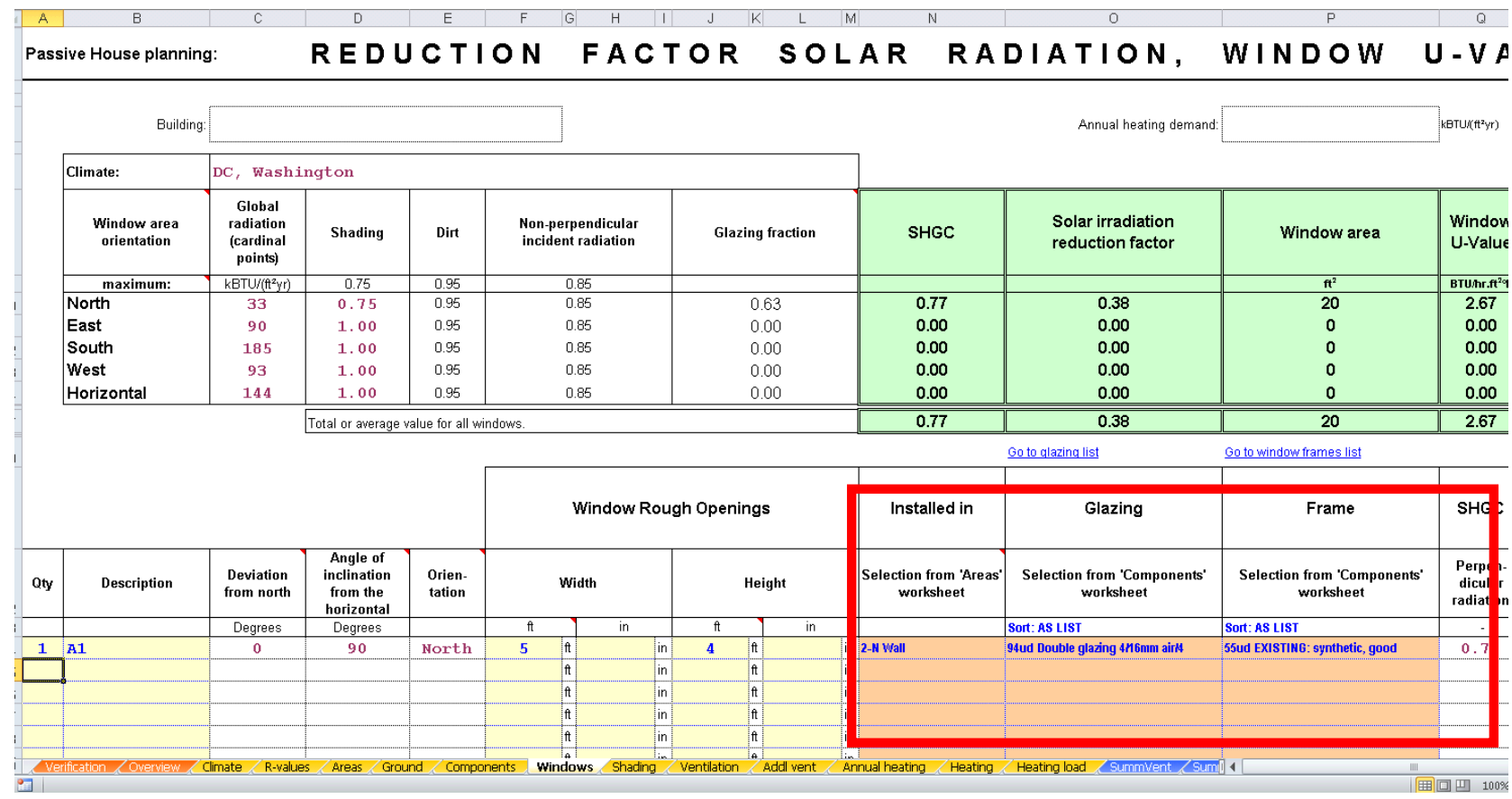

Figure 20. Drop-down boxes on the Windows tab allow the user to select the wall orientation it is associated with from the Areas tab, the glazing type, and the frame type

The only other necessary input is to indicate whether the window abuts another window or a wall on each side of the frame (see Figure 21). This adjusts the amount of frame area calculated and the overall U-value of the window. 


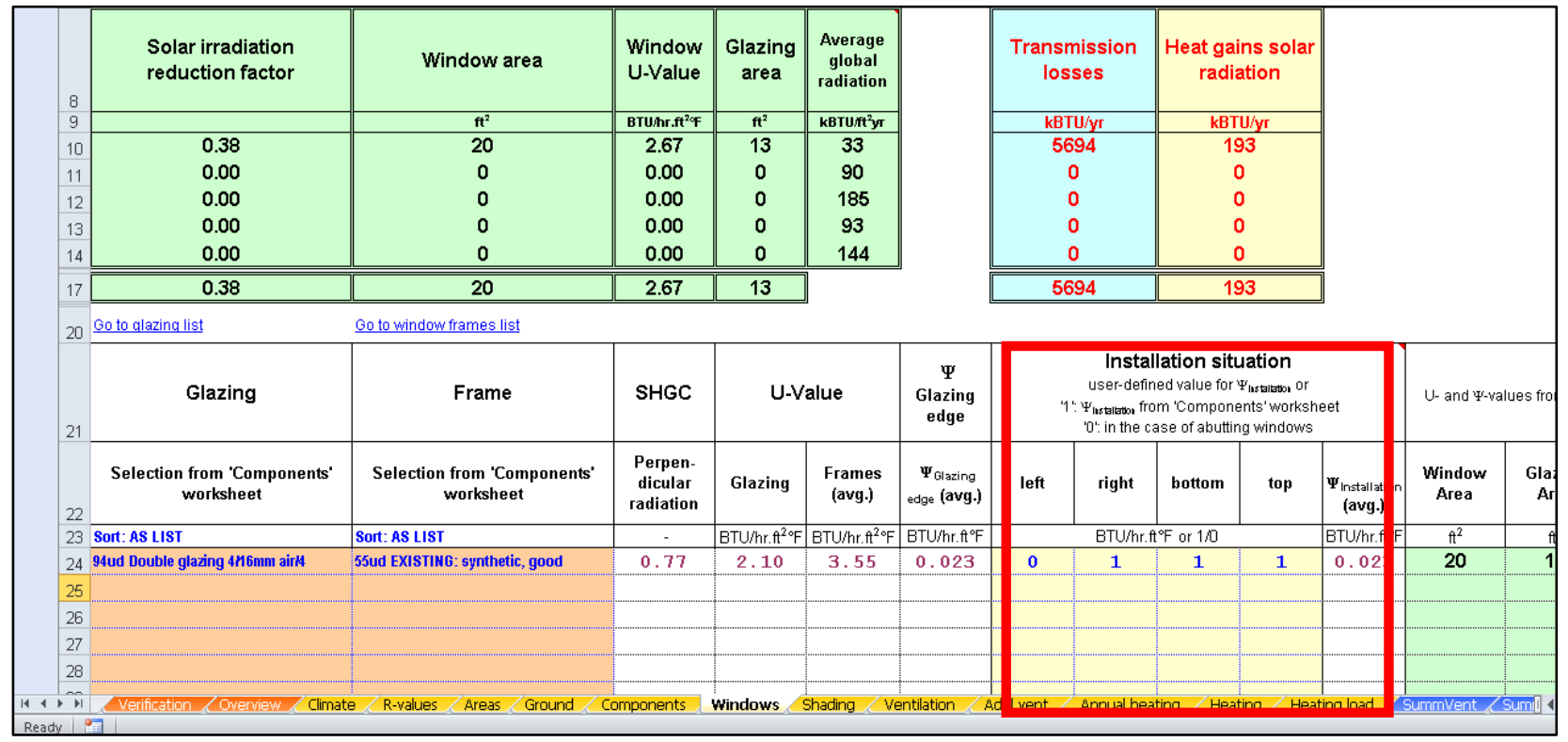

Figure 21. The user must indicate whether the window abuts another window or a wall.

\section{Shading}

Each window entered on the Windows tab will show up on the Shading sheet. Be sure to include any neighboring buildings, exterior structural shading devices, interior shading devices, selfshading from the home, and so on. Do not be overly conservative. Simply state the situation as it will be constructed. This sheet has an enormous impact on the solar gain calculations.

\section{Ventilation and Air Leakage Values}

Whether the house will follow PH ventilation requirements or ASHRAE 62.2, be sure to include the ventilation load in the design calculations. The PH methodology uses two distinct volumes in its design load calculations: (1) one for ventilation requirements that assumes a ceiling height of no more than $8.2 \mathrm{ft}$; and (2) one for calculating the air change rate for the air leakage calculation. This volume assumes interior dimensions were used and no interior walls were included in the volume. The design calculations depend on these two volumes (see Figure 22). 


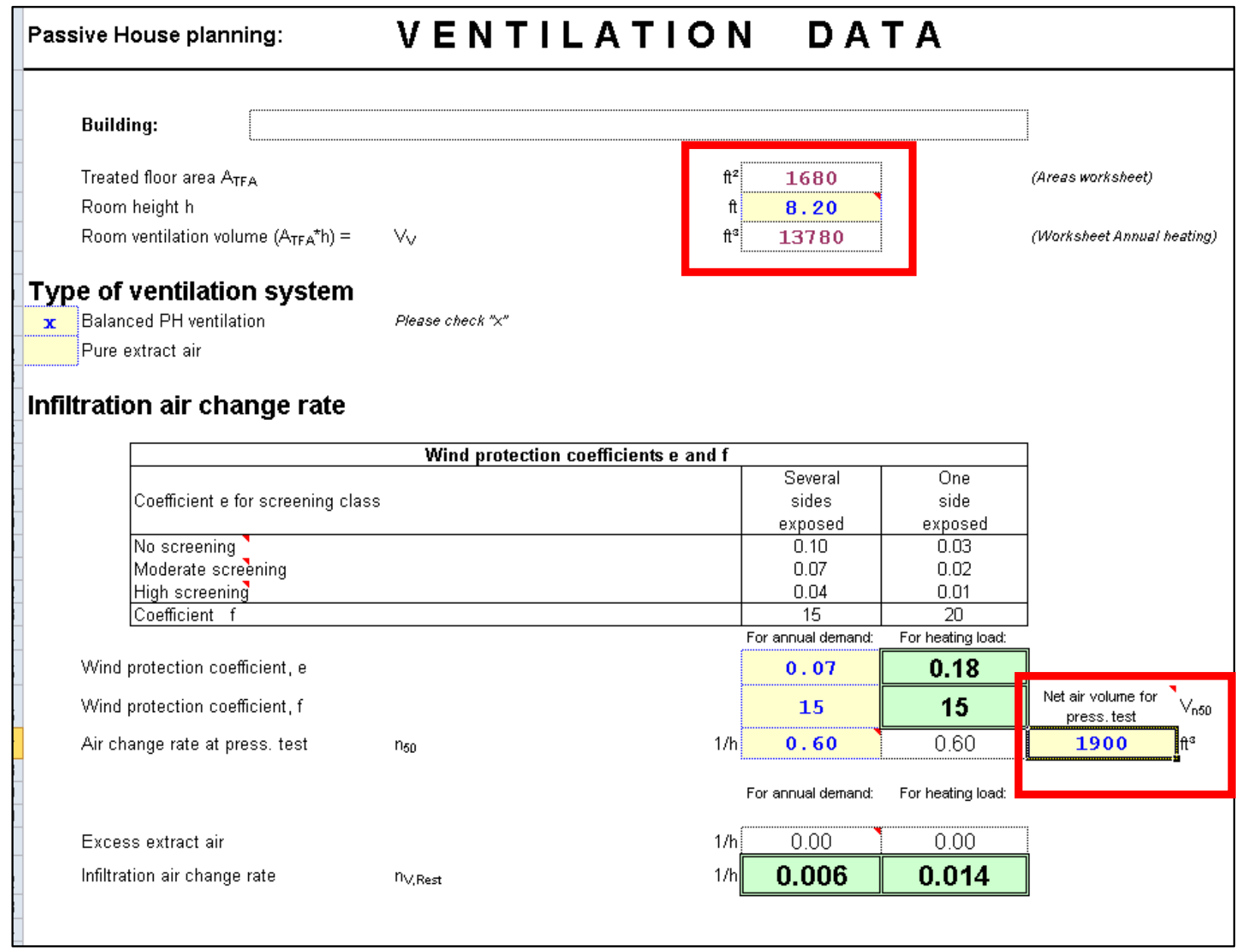

Figure 22. The Ventilation tab also accounts for air leakage.

Energy recovery or heat recovery ventilation is common in superinsulated homes because the ventilation load can comprise a significant fraction of the overall heating load. Enter the anticipated air change rate from mechanical ventilation. Typically, $\mathrm{PH}$ projects aim to maintain a minimum of $0.30 \mathrm{ACH}$. Adjust the inputs for Daily Operation Duration and the percent of the total maximum flow (Figure 23) at that duration to achieve the flow rates desired for each particular project. Maximum flow will be determined by the number of kitchens, baths, and laundry rooms and the number of occupants assumed. 


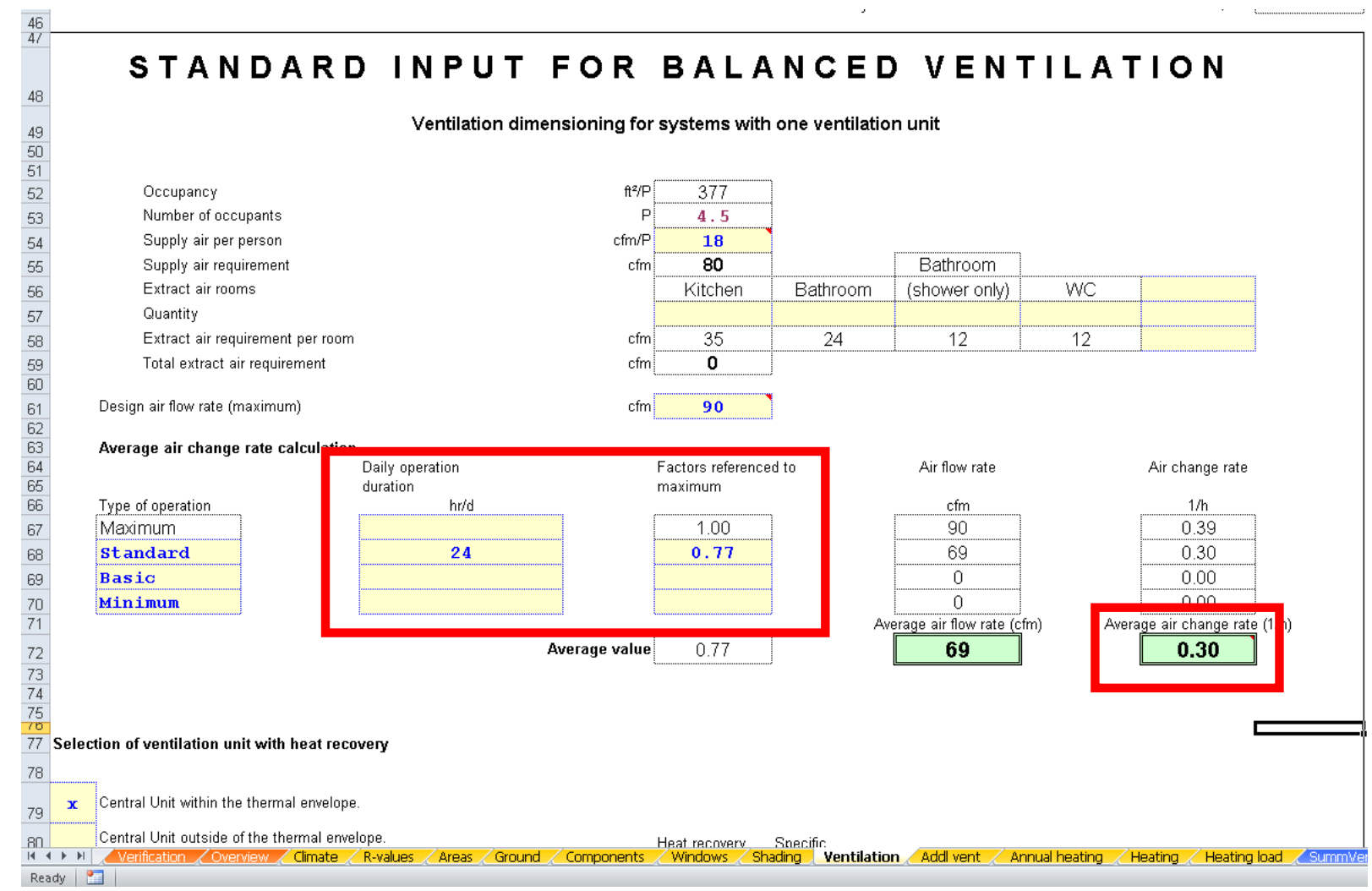

Figure 23. Ventilation rates can be adjusted to each particular project's needs.

Because air leakage will be verified in these homes, use an appropriate value here. Don't predict that the home will be leaky to provide a buffer to the load sizing. Superinsulated homes must have airtight shells to ensure proper hygrothermal performance. Advanced testing and multiple onsite inspections ensure that air leakage levels are low and should be accounted for in the heat load calculations.

Account for heat recovery as required to ensure the loads are properly calculated. A PH-certified product can be selected from the drop-down box, or a custom unit can be entered in the Components tab and then selected from the drop-down box (see Figure 24). 


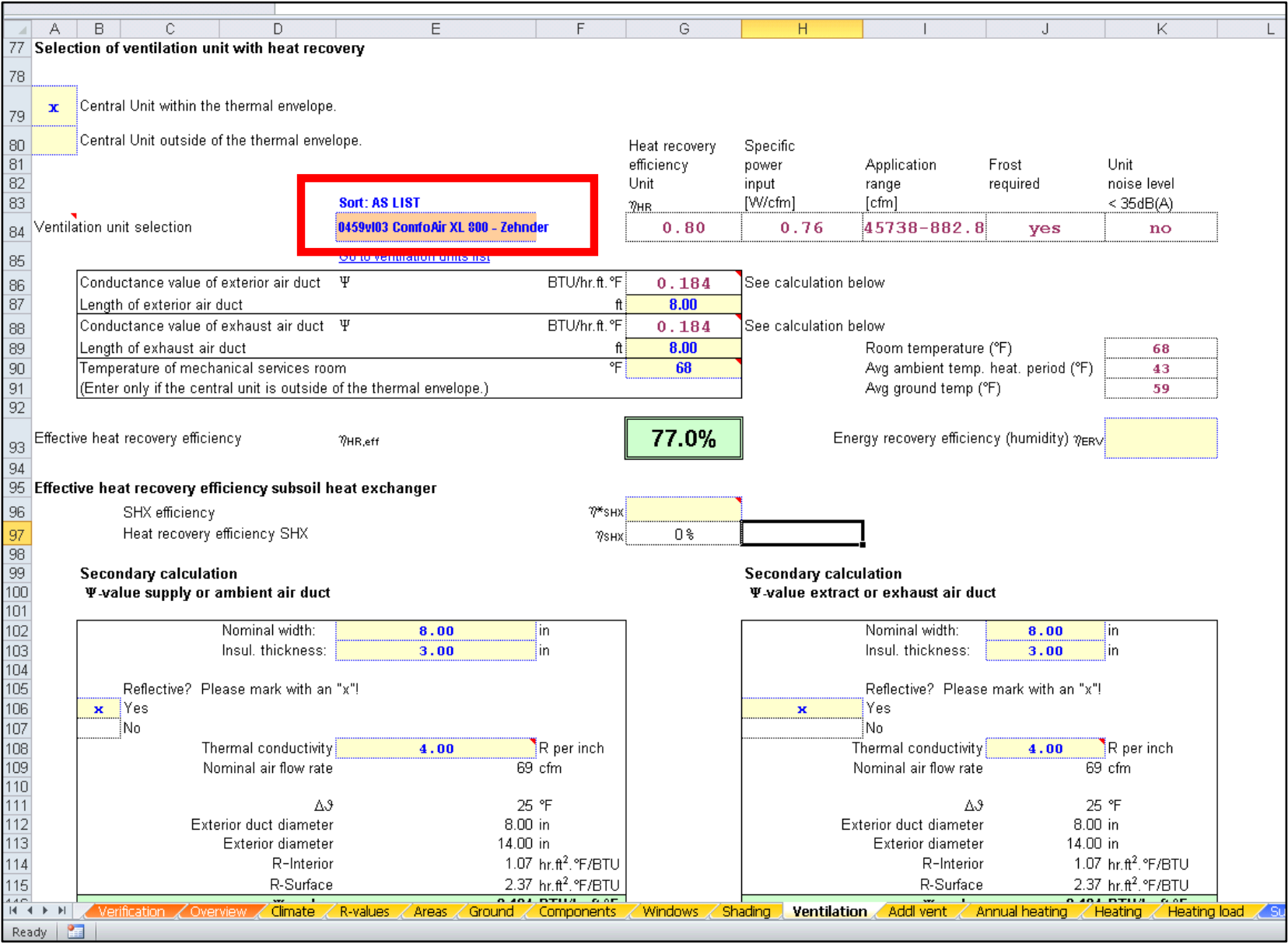

Figure 24. Select the ERV/HRV from the drop-down box highlighted. If the unit being used is not in the list, enter the information on the Components tab.

Once all the information in the required screens has been entered, the design heating load will be properly calculated. Check to confirm that values highlighted in Figure 25 have been calculated for each building assembly. 


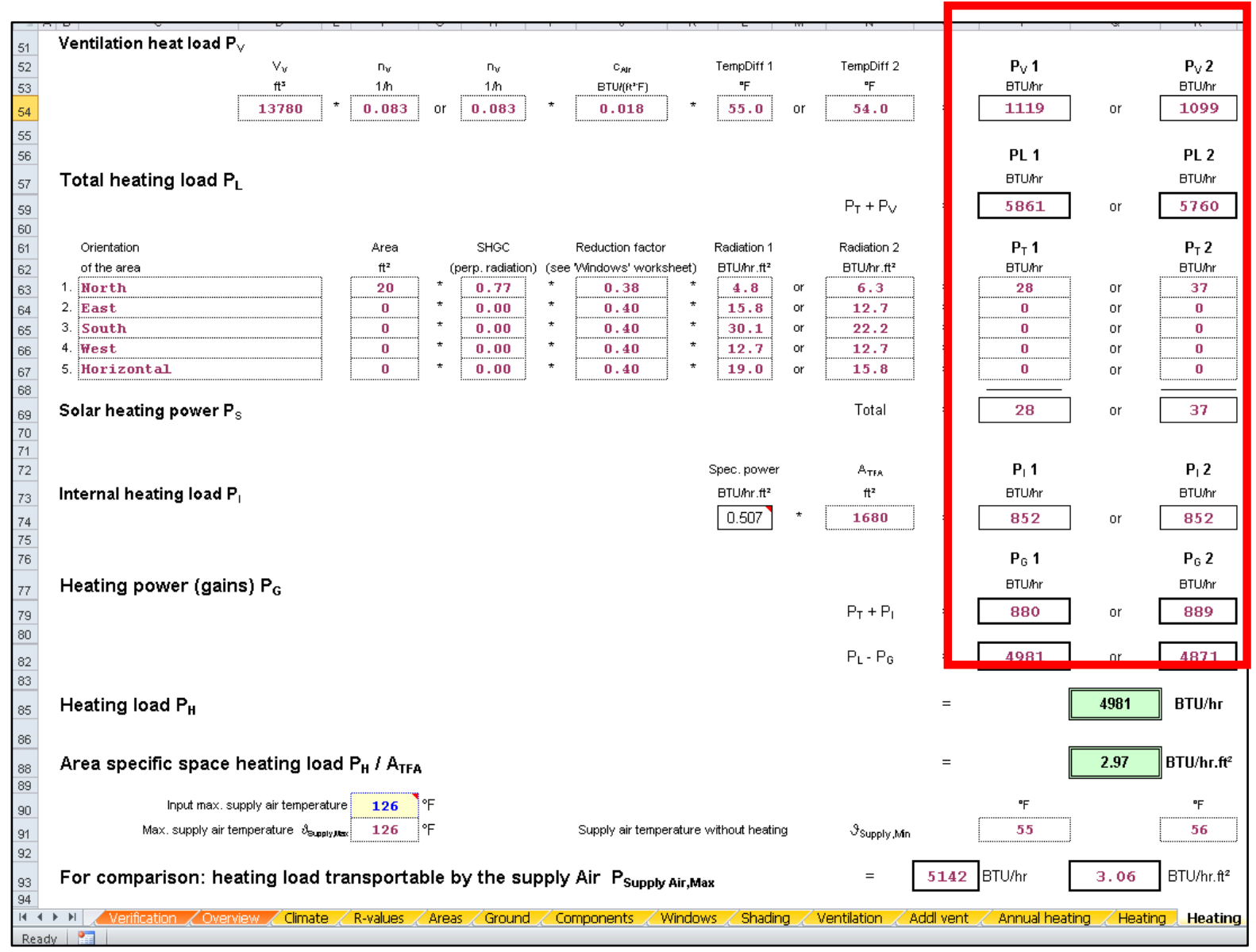

Figure 25. Each building component should have a Btu/h value in the columns to the right.

\section{Verification Procedures and Tests}

As noted earlier, testing and verification must be part of the project scope. If that is not the case, this design guide should not be used. As in any load calculations, the guide assumes that the specified efficiency and airtightness targets will be met.

\section{Field Inspections}

Several inspections should be planned throughout the construction process. Insulation levels, window efficiencies, mechanical equipment efficiencies, and quality of installation must be verified. Foundation insulation must be verified before slabs are poured. Airtightness measures should be verified throughout the construction process. The insulation installation should be closely inspected. Voids, gaps, and thermal bridges should be avoided. These increase energy use and the likelihood of condensation and comfort problems.

\section{Recommended Testing}

Air Leakage: Superinsulated buildings often undergo airtightness testing before insulation is installed. Most air leaks should be taken care of before insulation is in place. Even if spray foam insulation is used, extensive air sealing before insulation is necessary to reach these super airtightness levels. It is highly recommended that a test be conducted before drywall is installed. 
If the levels desired are not already achieved after insulation is installed but before drywall installation, the chances of reaching the low air leakage rates desired are significantly diminished. This is especially necessary when working with contractors who have never built such a structure.

HVAC Ductwork (if applicable): Duct leakage testing ensures that the ducts are adequately sealed to allow the conditioned air to reach its intended destination and reduce the chance for pressure differentials in the home. Such differentials can increase infiltration or exfiltration and should be avoided. Warm moist air should not be pushed into exterior building cavities in heating-dominated climates.

Mechanical Ventilation Flow Rates and Balancing: In a superinsulated airtight assembly, mechanical ventilation is a crucial component that removes excess moisture, carbon dioxide from the occupants, and odors or cooking fumes. Minimum ventilation rates are usually recommended; the options for increasing that flow rate when needed are often provided. The load for mechanical ventilation is included in the design, so the flow rates must be measured and corrected if they do not meet the specification. Too little airflow could result in high indoor relative humidity; too much could result in excessively high heating bills and relative humidity that is too low. 
